\title{
The 90th Anniversary of the Borissiak Paleontological Institute, Russian Academy of Sciences: from the "Golden Age" of Paleontology to New Perspectives
}

\author{
S. V. Rozhnov ${ }^{a, *}$ and A. Yu. Rozanov ${ }^{a, * *}$ \\ ${ }^{a}$ Borissiak Paleontological Institute, Russian Academy of Sciences, Moscow, 117647 Russia \\ *e-mail:rozhnov@paleo.ru \\ **e-mail:aroza@paleo.ru
}

Received October 12, 2020; revised October 19, 2020; accepted October 19, 2020

\begin{abstract}
The main directions and results of the Paleontological Institute's activities over the past 40 years are considered. The demand for paleontological research conducted by the Institute's scientists has shifted from stratigraphy and geological surveying towards the study of the evolution of the biosphere and evolutionary developmental biology. It is shown that the rapidly developing biological aspect of paleontological research continues to be largely based on a detailed analysis of the stratigraphic and geographic distribution of fossil organisms.
\end{abstract}

Keywords: history of paleontology, Precambrian, Phanerozoic, bacterial paleontology, astrobiology, brachiopods, bryozoans, echinoderms, corals, insects, mollusks, vertebrates, plants

DOI: $10.1134 / \mathrm{S} 0031030121020131$

It is no coincidence that the establishment of the Paleontological Institute in 1930 was in the heyday of paleontology in the Soviet Union. As in the rest of the world, the prosperity of paleontology in this country was due to the need for a systematic geological survey, in this case of a very large territory, to search for minerals during a time of rapid industrialization. The high demand for paleontology for stratigraphic purposes led to the organization of specialized paleontological teams at regional geological surveys, to produce keys, paleontological manuals and monographs. The Paleontological Institute rapidly became a necessary center for the development of methods for paleontological studies of various groups of fauna and flora and the creation of classical monographs of many of them, with accurate morphological descriptions and an indication of the stratigraphic and geographical distribution. Many paleontologists all over the vast country were in need of data from such studies to process their own material collected during fieldwork in the course of geological surveys. This time is correctly known as "the golden age of paleontology". During this period, which lasted about 50 years, a powerful cluster of world-class paleontological schools was established at the Paleontological Institute, new directions in science arose, the publication of the Paleontological Journal was organized, and a large number of monographs were published as the Transactions (Trudy) of the Paleontological Institute. These and many other achievements are described in detail in the special 184th issue of the Institute's "Trudy", published for its fiftieth anniversary (Paleontological Institute, 1980). Therefore, we will particularly discuss the changes that occurred at the institute during the last 40 years.

The "golden age" of paleontology had ended by the beginning of the 1980s. Geological surveys, on the territory of the USSR and the whole world, had sharply decreased. New methods of stratigraphy appeared, which, it seemed, no longer needed classical paleontology. The number of paleontologists began to decline rapidly. Due to the departure of old specialists and the absence of new ones, entire phyla of the organic world were left without sufficient study. The long-standing problem of storing collections became more acute. The premises of the old Paleontological Museum were so filled with exhibition samples, that it was no longer possible to let visitors in. The construction of a new museum building planned by the USSR Academy of Sciences was stalled due to lack of sufficient funding. However, circumstances helped. In 1984, the International Geological Congress was to be held in Moscow. The Paleontological Institute became one of the organizers of the section of paleontology and stratigraphy. Some of the employees were part of the organizing committee, others headed individual sections and conducted field excursions (Fig. 1). The congress was regarded by the country's leadership as an important political event. In the plan of its work, it was possible to include a visit by the par- 


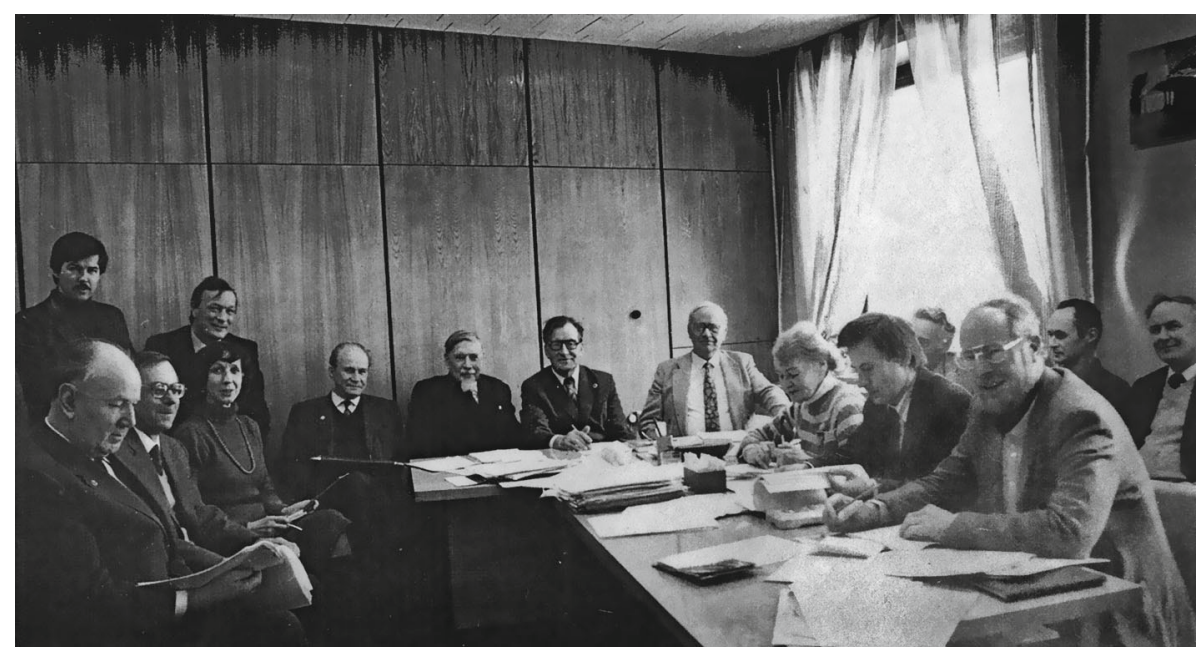

Fig. 1. Meeting of the organizing committee of the section of stratigraphy and paleontology of the International Geological Congress (Moscow, 1984); from left to right: V.A. Vakhrameev, unknown, M.A. Fedonkin, T.N. Koren, A.Yu. Rozanov, B.S. Sokolov, V.V. Menner, A.I. Zhamoida, J. Kaui, E.D. Zaklinskaya, Yu.B. Gladenkov, D.L. Kaljo, and S.V. Meyen.

ticipants of the Congress to the Paleontological Museum. Therefore, in the Resolution of the Central Committee of the CPSU and the Council of Ministers regarding the congress, a demonstration of the new Paleontological Museum was recorded, the building for which was to be completed by that time, and half of the halls were to be filled with exhibits. Information about the wonderful new museum became known throughout the world. Before the opening of the museum, the entire institute was absorbed for several years with the development and creation of the museum's exhibitions, and its relocation. In 1984 some of the halls were opened for the participants of the Geological Congress. Despite the fact that only half of the future museum was shown to the congress participants, its design and unique exhibits made a great impression (Fig. 2). The revision of the remaining halls and their exhibitions was only completed in 1987, when the museum was opened to the general public (Fig. 3). Thus, it immediately became one of the largest and best natural history museums in the world (Rozanov et al., 2012). Its discovery solved the problem of exposing many unique paleontological objects for public view, although there was still a lot of exhibition material in storerooms, enough to fill another museum. However, there was still not enough space to store scientific monographic material. The planned laboratory building with modern storage has not yet been built, and the problem of preserving the collections remained extremely acute. The departure of older specialists and the absence of younger successors compromised the safety of collections collected over many years. Huge collections of various groups of animals and plants collected by previous generations provided a large resource for the continuation of scientific research in the face of the financial impossibility of conducting extensive and productive paleonto- logical expeditions., but all these collections required special storage and accounting. This problem was partially solved by organizing a monographic department, whose task was to record and store specimens described in articles and monographs. New areas were organized for storing monographic collections. During these difficult times, the institute was able to rebuild part of the building and create a new repository of type material. Patricia Vickers-Rich (Australia) greatly assisted in equipping this new part of the repository, contributing not only to the internal equipping of shelves and special cabinets, but also to the receipt of collections of ancient organisms from different countries, as a result of which the institute houses one of the largest and most interesting collections of Vendian organisms. The formation of the monographic department has significantly improved the collection storage system, but the problem is not yet completely solved.

Perestroika in the Soviet Union and disintegration of the USSR had various consequences for the institute. On the one hand, funding for the institute sharply decreased, scientists became semi-impoverished people, barely making ends meet. Young people did not want to work in such conditions and did not go into science. This put the institute at the brink of extinction, but for the opportunity to organize foreign exhibitions of paleontological material that was not included in the main exhibitions of the museum. This material was of very high quality, and its exposure in various countries aroused great interest and brought the institute a significant financial profit, which made it possible to maintain employee benefits at an acceptable level. An important element in the agreement of exhibitions was an article on payment for the presence of one or two researchers for scientific work in the exhibition areas. Thanks to this, the employees of the 


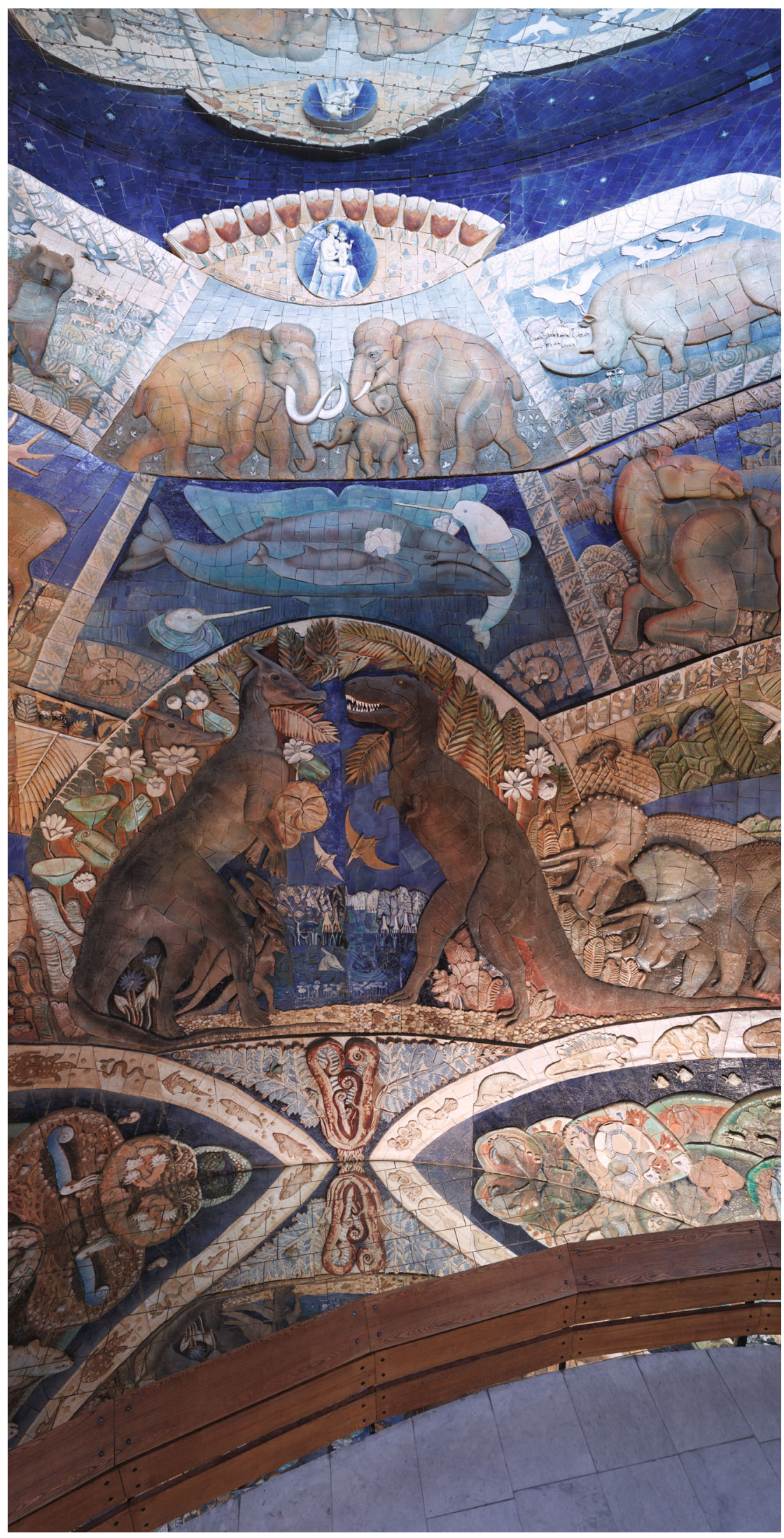

Fig. 2. Tree of life. 


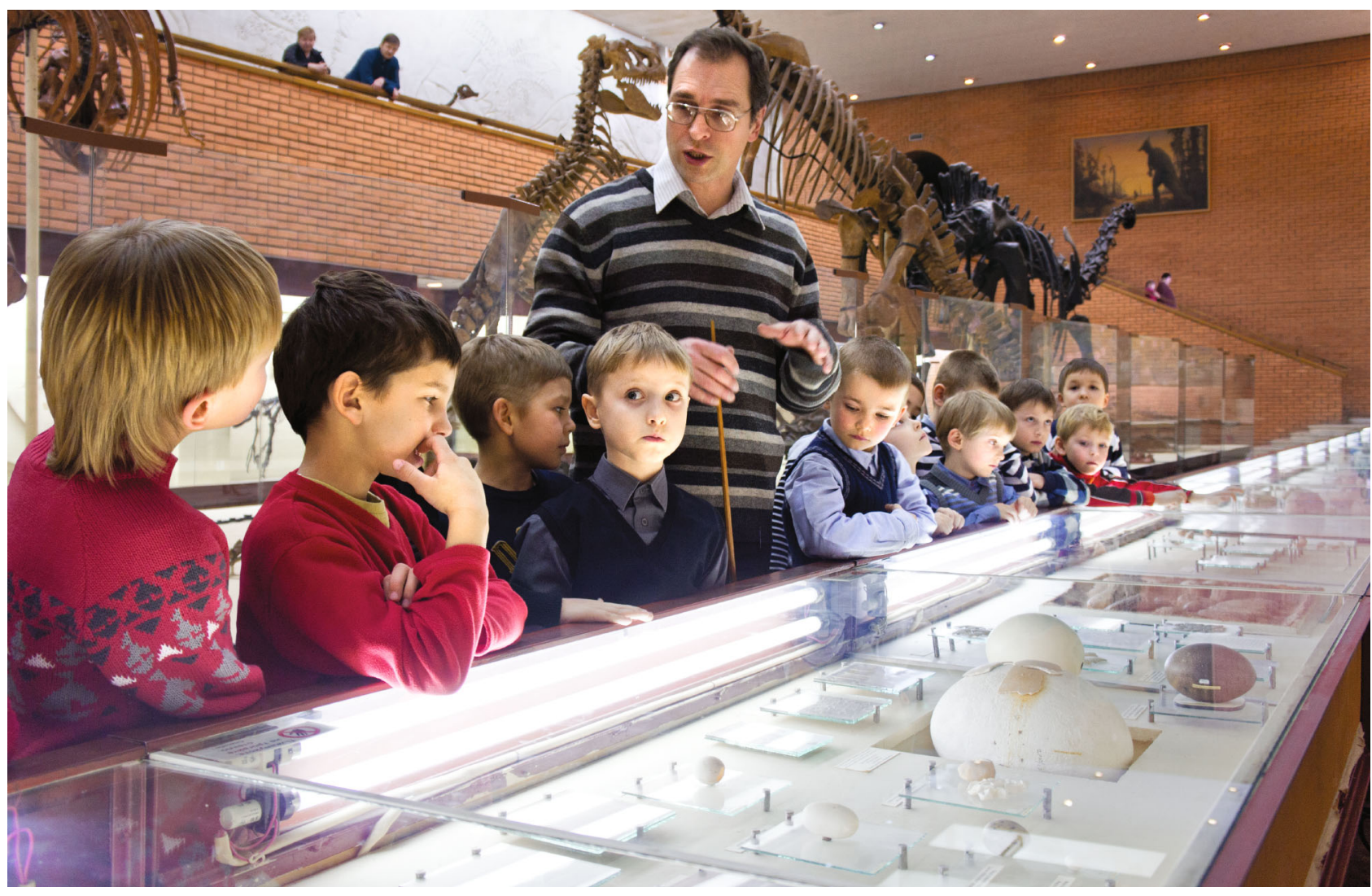

Fig. 3. Excursion in the museum.

institute dramatically expanded their international contacts with colleagues, and the money they earned helped them to endure the financial difficulties of the 1990s. Overseas exhibitions were very important in maintaining the financial and scientific stability of the institute. They promoted the remarkable collections of the Institute and the scientific achievements of employees abroad (Finland, France, Poland, Germany, Korea, Sweden, Japan, USA, Italy, Cyprus, etc.) and often facilitated extensive joint work of the Paleontological Institute staff with foreign specialists. Collaboration with Australian scientists proved to be especially productive, since the exhibition, called "The Great Russian Dinosaurs Exhibition", was held in different cities of Australia for four years. Many collaborative articles have been published by Australian scientists and Paleontological Institute staff, including a large popular monograph on the four-year history of the exhibition in Australia (Vickers-Rich and Rozanov, 2018). Several Australian companies, including Qantas Airways, actively sponsored the Australian "The Great Russian Dinosaurs Exhibition". Qantas Airways also partially sponsored the institute's fieldwork.

The famous Swedish scientist and inventor Hans Rausing, who is mostly known for the invention of "Tetra Pak" packaging for liquid products, rendered great financial assistance. Having become an extremely wealthy man, Hans Rausing did a lot of charity work in Russia in the nineties, helping scientific and educational institutions. He was deeply impressed by his visit to the Paleontological Museum (Fig. 4), after which he twice donated large sums to the institute and the museum. Thanks to his donations, significant measures were taken in the museum to preserve the skeletons on display, and important scientific equipment was acquired. At the same time, the administration of the institute not only took care of equipping with modern instruments, but also created such a layout of the instrument base, which ensured wide accessibility to the instruments of the institute staff, students and all collaborators from other institutes. The main thing was not the super-uniqueness of the devices, but their wide availability at the right time. Also, thanks to the support of Hans Rausing, works and catalogs were published, financial assistance was provided to employees in the difficult years of the early nineties. His assistance to the institute in the nineties largely predetermined the stability and uniform work of the institute in those difficult times. A portrait of Hans Rausing hangs in the lobby of the museum.

Changes in the Soviet Union in the late 1980s, and in Russia after the Soviet Union's collapse, provided a broad opportunity for scientists to collaborate with 


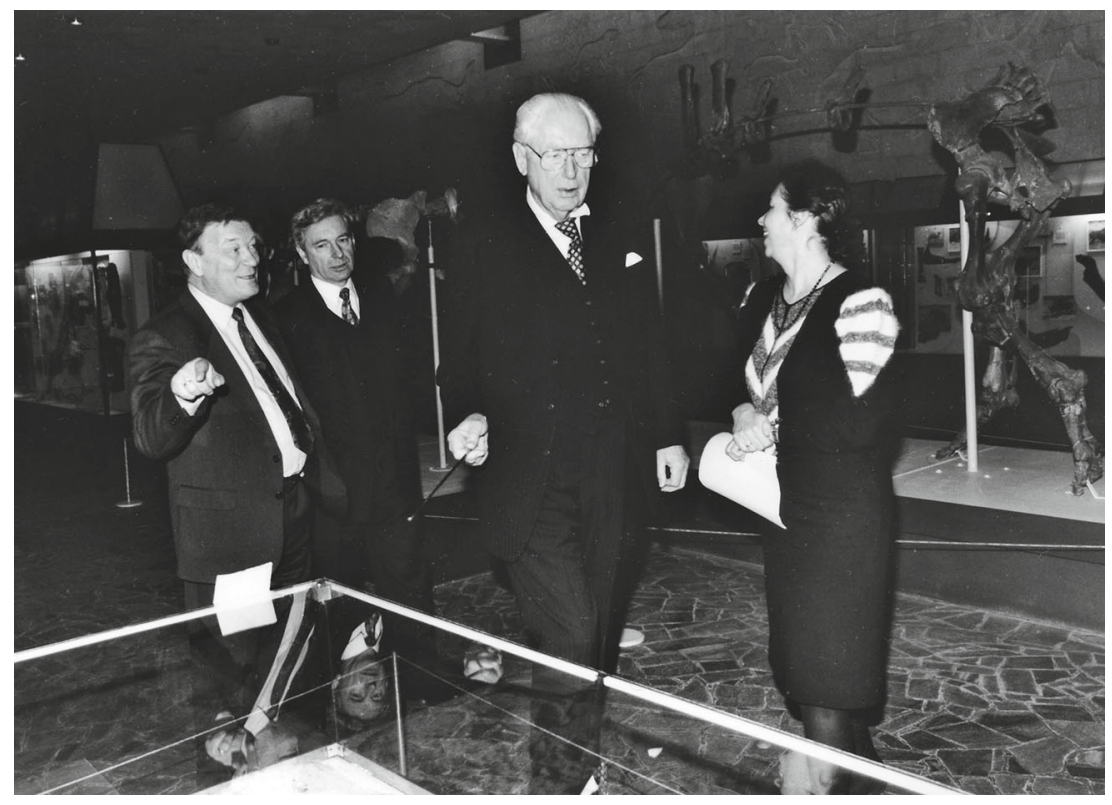

Fig. 4. Paleontological museum: A.Yu. Rozanov, Sheremetyev, H. Rausing, T.B. Leonova.

their foreign counterparts. Participation in paleontological exhibitions by researchers of the Paleontological Institute in many cases provided a financial opportunity for such cooperation. For example, during the exhibition's stay in Iowa, one of the authors managed not only to study an extensive collection of echinoderms, but also to personally meet many colleagues in the United States. Thanks to these meetings, a joint Russian-American grant "Development of echinoderms on the isolated Ordovician continents" was well substantiated and received. This gave a remarkable impetus to the development of international cooperation in the study of Paleozoic echinoderms not only in Russia, but also in the United States. It turned out that American colleagues had hardly traveled outside the United States before. For the famous US paleontologist J. Sprinkle, a fieldwork grant to Moscow and the Leningrad Region provided his first trip outside his country. Later, he continued travelling and visited many international conferences in different countries. Paradoxically, in the difficult 1990s, the institute developed extensive and very fruitful scientific ties with NASA (branches in Huntsville and Houston), with the University of California (especially in its branches in Berkeley). The Institute actively participated in the work of the International Society of Optical Engineers (SPIE-Society of Photo-Optical Instrumentation Engineers), where, together with NASA employees, the astrobiology section was organized, the works of which (16 issues) were regularly published every year. The institute also collaborated with the University of Cambridge (Cambridge Arctic Shelf Program), which resulted in large reviews on the stratigraphy and oil-bearing capacity of several regions of Russia. The well-known Polish paleontologist A.
Urbanek, in parallel with his duties as a representative of the Polish Academy of Sciences in the Russian Academy of Sciences, worked fruitfully for several years at the Paleontological Institute.

During the same period, an international subcommittee on the Cambrian system was active, which included several Russian scientists, including employees of the Paleontological Institute. The Subcommittee prepared and published correlation schemes for the Cambrian of the Siberian Platform, the Altai-Sayan Fold Region, and the East European Platform. One of the most important events associated with the activities of the Institute was the recognition by UNESCO of the Lena Pillars, Yakutia, a monument of world scientific heritage, as this area is among the most important regions in the history of the Earth, the center of origin of the skeletal fauna, which became the basis for the entire skeletal fauna of the Earth (Fig. 5). This natural monument is characterized by the highest taxonomic diversity of the Early Cambrian biota, more than half of all known genera and $85 \%$ of the families of the world Cambrian fauna. The Lena Pillars are a standard for the general stratigraphic zonal tier scale of the Lower Cambrian, developed by I.T. Zhuravleva, L.N. Repina, V.V. Khomentovsky and A.Yu. Rozanov.

The participation of the Institute's staff in international conferences and projects has become commonplace. International conferences at the Institute began to be organized more often. Within the framework of inter-academic cooperation with Great Britain, M. Benton and S.V. Rozhnov in 2016 organized a round table on contemporary problems of paleontology, which ended with a reception at the British Embassy. In 2018, the Institute successfully hosted the 


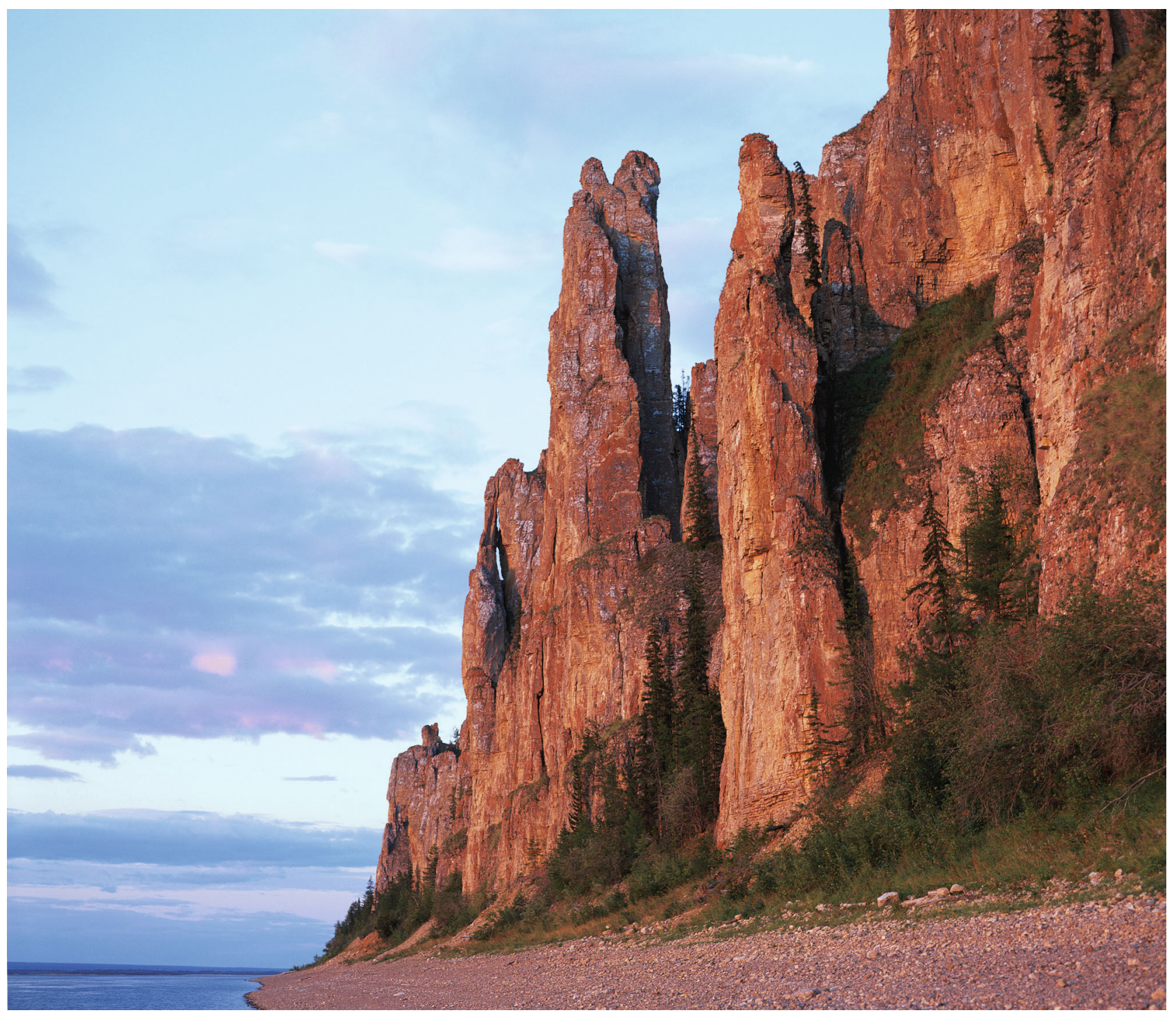

Fig. 5. Lena Pillars.

$10^{\text {th }}$ European Conference on Echinoderms, which brought together more than a hundred participants from many countries of the world.

At the same time, the research of scientists in the Institute laboratories, scientific programs and received grants was actively developing. The institute's laboratories continued to reflect unification based on the study group. This work was mainly related to the monographic study of taxa from the localities of Russia, the "zone of responsibility" of the Paleontological Institute in a divided world, and on the accumulated collections from other territories of the former USSR and Mongolia.

Special mention should be made of the paleontological study of Mongolia. It was held as part of the Joint Soviet-Russian-Mongolian Paleontological Expedition (SSMPE/SRMPE), the fiftieth anniver- sary of which was solemnly celebrated by the Academies of Sciences of these two countries in 2019 (Fig. 6). The history of the expedition and the colossal results of its activities have already been covered in detail in several publications (Rozhnov et al., 2014; Lopatin, 2019a; Rozhnov, 2019; Rozanov et al., 2020). The main achievements of the expedition are associated not only with the discovery and description of vertebrates, but also with a detailed study of the flora and invertebrates-brachiopods, bryozoans, echinoderms, corals and other groups. The study of invertebrates played an important role in the development of the Paleozoic stratigraphy of Mongolia (Fauna, 1996). But it is especially worth noting here the study of Cambrian phosphorites (Shkolnik et al., 1999). Their microbial origin was revealed, and later it was shown that all sedimentary phosphorites were formed as a result of the vital activity of bacteria. Hence, a new 


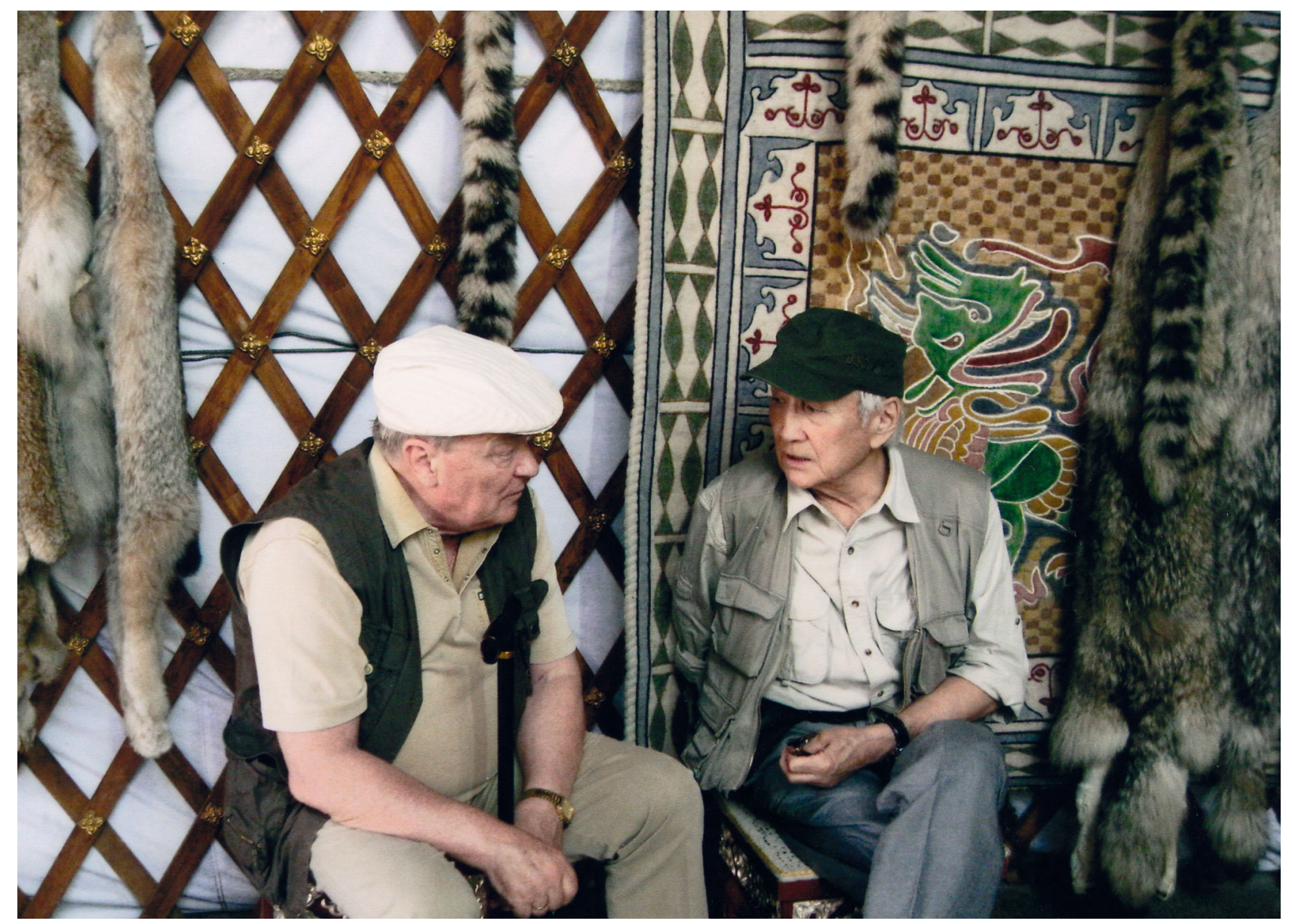

Fig. 6. Scientific supervisors of the Joint Russian-Mongolian paleontological expedition A.Yu. Rozanov and R. Barsbold.

direction of research began-bacterial paleontology, which rapidly expanded the field of activity, from sedimentology to astrobiology, from "revitalization" of the most ancient Archean rocks to the search for fossilized organic remains in meteorites (Rozanov et al., 2001). This led to active collaboration with NASA and the Joint Institute for Nuclear Research in Dubna.

Another important direction related to Precambrian research was carried out in the Laboratory of Precambrian Organisms. This laboratory has received worldwide recognition thanks to the systematic excavations of Vendian organisms on the coast of the White Sea, which brought unique material for a convincing reconstruction of the morphology and lifestyle of many representatives of the ancient fauna. This laboratory was organized by Academician B.S. Sokolov in 1977. At first it was called the Laboratory of Precambrian Paleontology, and the paleobiology of Metazoa immediately became its central focus of research (Sokolov, 1997). Due to the concentration of efforts of many researchers and, first of all, Paleontological Institute staff, over two decades, rich localities of Vendian macroremains were discovered in Podolia, Southeastern White Sea region, Middle and South
Urals, on the Olenek Uplift. Of particular importance is the Zimnie Gory locality, discovered in 1977 (Fedonkin, 1981), which surpasses all other Vendian locales in the world in terms of abundance, diversity, and quality of preservation of fossils. Numerous publications of this time describe dozens of genera and hundreds of species of "body" macroremains and traces of animal life (see, for example, Fedonkin, 1987). This heroic period ended with the publication of the fundamental two-volume monograph "The Vendian system. Historical-geological and paleontological substantiation", published in Russian (1985) and in English (1990).

Further studies were associated with deciphering the details of the anatomy of Vendian macroorganisms, reconstruction of the features of their auto- and synecology. As a result, to date, the Paleontological Institute has accumulated the world's largest collection of fossil remains of Vendian macroorganisms, which contains unique specimens of most known species. In the taphocenoses of the Vendian shallowwater burials, which were previously considered almost exclusively metazoic, the presence of microbial colonies, thalli of metaphytes, giant structures of pro- 
tists, multicellular animals, including possible representatives of sponges, cnidarians, polychaetes, "protomollusks", arthropods, as well as groups of unknown origin, not known in the Phanerozoic (Petalonamae, Proarticulata and Trilobozoa), was established. In several species of "classical" Vendian animals, for the first time in the fossil record, traces of feeding and movement, intravital injuries with signs of tissue regeneration were revealed (Ivantsov, 2013; Ivantsov et al., 2019a, b); the composition and structure of a number of communities is described (Zakrevskaya, 2014).

In 1977, the Laboratory of the Oldest Skeletal Organisms was established, which was quickly replenished with young personnel; as a result of the joint work of all employees, it quickly turned into a world center for the study of the most ancient organisms. Its employees study mainly skeletal Cambrian organisms, the sequence and features of their appearance in the geological record. The results of joint research have been published in a number of monographs devoted to individual regions: Siberia, Mongolia, Canada, Australia and China (Voronin et al., 1982; Voronova et al., 1987; Rozanov et al., 1989, 2010; Parkhaev and Demidenko, 2010), and in numerous articles, and the laboratory itself has become a recognized world school for the study of ancient organisms. Due to detailed paleontological studies carried out in the laboratory, zonal stratigraphic schemes of the Lower Cambrian for different regions were developed and entered into practice. In addition, the laboratory participated in the creation of correlation schemes within the framework of the International Subcommission on the Cambrian System and the Development of the Lower Cambrian stages, which were adopted in the USSR (Varlamov et al., 1984, 2008; Astashkin et al., 1991, 1995; Cambrian ..., 2008).

In the process of diverse studies, bacterial paleontology, a new direction was established, which confirmed the biogenic origin of phosphorites (Shkolnik et al., 1999; Zhegallo et al., 2000), and later showed the role of bacteria in the formation of other minerals (iron, manganese, bauxite and others) (Rozanov and Zhegallo, 1989; Rozanov et al., 2001; Shkolnik et al., 2004, 2005; Astafieva et al., 2011). Due to the results of the study of space material, the Presidium of the Russian Academy of Sciences decided to create a Scientific Council on Astrobiology under the Presidium of the Russian Academy of Sciences.

The laboratory has successfully developed work on the study of the most ancient representatives of different groups of fauna (brachiopods, ostracods, archaeocyaths, agnosticids). Among them, the small-shell fauna, which characterizes the first stages of the Cambrian evolutionary explosion, is of particular importance. There are many new data on this fauna, especially on the most ancient gastropods. Based on the interpretation of morphologically diverse Cambrian fossils, it was shown that mollusks of the classes Polyplacophora, Monoplacophora, Gastropoda, and Bivalvia were isolated at the Precambrian-Cambrian boundary, i.e., from the beginning of the paleontologically documented evolutionary history of the type (Parkhaev, 2017).

The Laboratory of Protistology, established in 1993, studies Phanerozoic marine protists, primarily calcareous nannoplankton, radiolarians, foraminifera, and other groups of microscopic fossil organisms, in particular, calcareous algae, ostracods and conodonts. A separate area is Carboniferous paleosols and their microbiota. The method of quantitative paleoecological analysis of communities was widely used to reconstruct the settings of ancient sea basins: the history of the Laptev Sea shelf flooding in the Holocene was reconstructed from ostracods (Stepanova, 2006); the temperature regime of the sea basin of the East European Platform was reconstructed from calcareous nannofossils during the Campanian and Maastrichtian (Ovechkina, 2007); a change in fusulinid complexes was revealed as a response to the cyclicity of the Middle Carboniferous sea basin of the Moscow region (Baranova et al., 2014). The development of stratigraphic schemes of the Carboniferous and Upper Cretaceous deposits of the East European Platform was carried out (Olferyev and Alekseev, 2005), the selection and justification of markers of the boundaries of a number of stages of the Carboniferous system of the international chronostratigraphic scale was carried out. The change of foraminifera in the Upper Eocene and Oligocene of Kamchatka has been studied in detail, and calcareous algae and foraminifera of the Upper Visean and Serpukhovian stage of the Moscow region have been studied (Gibshman, 2003; Gibshman and Alekseev, 2017). Information on the morphology of radiolarians has been generalized, a new taxonomy for this group of plankton has been developed (Afanasieva and Amon, 2006), and the stratigraphic significance and biogeography of Devonian radiolarians in Russia have been studied. The radiolarian assemblages of the Upper Cretaceous of the Moscow Region are recognized. In the south of the Moscow Syneclise, different types of Carboniferous paleosols have been identified for the first time and used in the cyclic analysis of sections and detailed stratigraphy. In the Moscow Region, a detailed paleontological characteristic of the type sections of the Serpukhovian, Moscovian, Kasimovian, and Gzhelian Stages was obtained, which is necessary to substantiate their international status (Makhlina et al., 2001; Alekseev and Goreva, 2009).

In the Laboratory of Mollusks, by this time, two main directions were combined, previously developed in separate laboratories. One of them was associated with the study of bivalves and gastropods of the Cenozoic of the brackish seas that formed on the site of the closing Tethys Ocean. This field was covered by works of L.A. Nevesskaya, L.B. Ilyina, O.V. Amitrov, 
N.P. Paramonova, S.V. Popov, I.A. Goncharova. Papers and monographs on the fauna of this region culminated in the Atlas of lithological-paleogeographic maps of Paratethys, which reflects the paleogeographic history of this vast sea stretching from the Prealpine Trough to Central Asia on a modern and reconstructed basis (Atlas ..., 2000). In parallel with these studies, L.A. Nevesskaya $(1998,1999)$ created a unique two-volume summary "Stages of development of the benthos of the Phanerozoic seas", which describes the characteristics of benthic marine communities, starting with the Cambrian. In the last years of her life, Nevesskaya prepared a fundamental handbook on bivalve mollusks, which became the modern version of "Fundamentals of Paleontology" (Nevesskaya et al., 2013).

In the early 2000s, a series of monographs (four volumes) "Biogeography of the Northern Peri-Tethys during late Eocene-Early Miocene" was published. In these works, on the basis of data on different groups of marine and terrestrial organisms, the stratigraphy and paleogeography of the basins of Western Eurasia from the Late Eocene to the Early Miocene, the biogeography of the water areas of the ancient Mediterranean and Paratethys and the land surrounding them are considered (S.V. Popov, O.V. Amitrov). In recent years, the study of sedimentation conditions was carried out by an international team using geochemical and paleomagnetic methods (Popov et al., 2016).

The second direction, now headed by the head of the laboratory T.B. Leonova, was associated with the study of a huge variety of fossil cephalopods. This field dates back to the works of V.E. Ruzhencev, who, relying on the experience of his predecessors, primarily A.P. Karpinsky, developed a methodology for the comprehensive study of ammonoids. This technique became the basis for the reconstruction of morpho-, onto- and phylogenesis, the origin of the Paleozoic ammonoids, and the pathways and rates of their evolution. The results of these studies have been published in many papers and monographs, which brought the laboratory a well-deserved prestige all over the world (Leonova, 2002, 2011; Nikolaeva and Bogoslovsky, 2005; Mitta, 2019). Monographs by V.N. Shimansky on Devonian-Triassic cephalopods is an important contribution to the study of fossil nautiloids. In recent decades, the team has been replenished with new employees, and the research topics have significantly expanded. In addition to traditional phylogenetic and biostratigraphic works, papers on morpho-ecological and biogeographic orientation have been published (e.g., Barskov et al., 2008). The richest localities for Permian cephalopods and gastropods were discovered in the Permian reef deposits of the Kirov Region and Bashkortostan. Numerous papers and monographs have already been published on the Middle Permian (Barskov et al., 2014; Mazaev, 2015) and AsselianArtinskian mollusks (Mazaev, 2019; Leonova, 2019). These studies made it possible to significantly refine the stratigraphy (to compare the Roadian Stage of the International Scale with the Kazanian Stage of the East European scale), as well as to expand knowledge of the biogeography and ecology of Paleozoic cephalopods. Since 2006, the laboratory has been organizing the All-Russian conference "Modern problems of studying cephalopods. Morphology, taxonomy, evolution, ecology, biostratigraphy", which attracts almost all active cephalopod workers of our country and some foreign colleagues.

Most of the work of the "Laboratory of arthropods" is related to the study of fossil insects. The staff of this laboratory headed by B.B. Rodendorf became world recognized as founders of paleoentomology. This laboratory, already world-famous, began the 1980s with a generalization of the previous successes of domestic and world paleoentomology in the collective monograph "Historical development of the insect class" (1980), which later expanded into the fundamental English-language collective volume "History of Insects" (2002). At the same time, monographs were published on the historical development of individual groups of insects (Rasnitsyn, 1980) and on the composition and structure of specific ancient communities (the Early Cretaceous Lake Manlai, 1980). Collective paleoentomological and paleobiocenological studies continued further. On the basis of extensive collections of insect fossils stored in the laboratory (about 220 thousand specimens at the end of 2019), and using all available literature and employees' own observations when studying foreign collections, collective generalizing works were carried out on various aspects of paleoentomology and evolutionary biology in general, such as the dynamics of biological diversity in the Paleozoic (Aristov et al., 2013), the diversity of insects and its dynamics in the Cretaceous, especially based on data from fossil resins (Rasnitsyn et al., 2016), and, finally, the dynamics of insect diversity in general, from the Carboniferous to the present (Dmitriev et al., 2018). Studies of theoretical aspects of evolutionary biology have developed, such as general and paleontological aspects of the holistic (epigenetic) theory of evolution and the methodology of phylogenetics, taxonomy and nomenclature (Rasnitsyn, 2006; 2020), paleoecology and the theory of evolutionary biocenology (Zherikhin, 2003). Special work has been done on the history and methodology of paleoentomological research (Zherikhin et al., 2008). All this happened against a background of intensive routine work on the study of insect fossils and in related biological areas, resulting in hundreds of publications in domestic and foreign journals. The laboratory staff is involved in extensive fieldwork to collect material, both throughout Russia and abroad (in Mongolia, Spain, the USA, and also collecting comparative material on relict modern insects in Chile and Australia). In recent years, the laboratory has been sending two, sometimes up to four, expeditionary teams a year. 


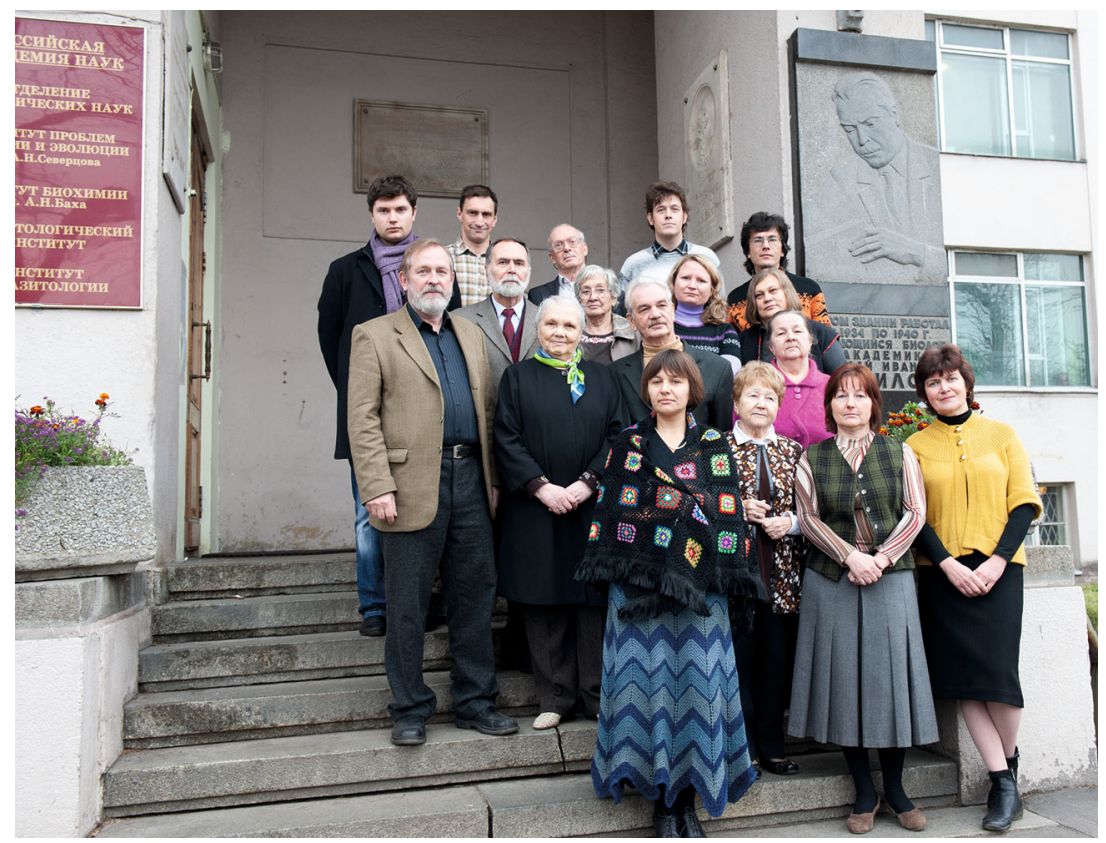

Fig. 7. The invertebrate laboratory at the entrance to the building of the Branch of Biological Sciences, where part of the institute's laboratories is located: G.V. Mirantsev, A. Ernst (colleague from Germany), S.V. Rozhnov, A.N. Soloviev, S.S. Lazarev, A.V. Pakhnevich, A.V. Markov, R.V. Goryunova, G.A. Afanasieva, I.N. Manankov, A.V. Koromyslova, I.O. Renge, A.A. Madison, L.A. Viskova, V.T. Antonova, O.B. Weiss, V.B. Kushlina. 2009.

A.G. Ponomarenko showed that throughout the Permian, fossil insect assemblages, according to the proportion of families emerging and dying out, form a sequence corresponding to their age. At the stages of declining diversity, extinction does not increase; on the contrary, morphogenesis decreases. It was concluded that diversity increases or decreases to a greater extent for internal, rather than external, reasons.

Since 1997, the Laboratory of Higher Invertebrates unites the independently existing laboratory of brachiopods, headed by G.A. Afanasieva, bryozoan laboratory headed by L.A. Viskova, and the office of echinoderms, organized in 1979 at the initiative of R.F. Hecker, led by A.N. Soloviev (Fig. 7). This merger was due to a decrease in the number of researchers on bryozoans and brachiopods. Nevertheless, even in such a reduced form, experts on bryozoans and brachiopods published a significant number of works on monographic studies of large faunas and on individual taxonomic groups (Afanasieva et al., 2003; Alekseeva et al., 2006; 2018; Koromyslova, 2011). Viskova (2008) described unique Early Mesozoic bryozoans. A detailed history of the study of bryozoans at the institute is described in a special article (Viskova and Koromyslova, 2011). I.N. Manankov, based on a monographic study of the Carboniferous and Permian brachiopods, substantiated the stratigraphy and paleogeographic features of the territory of Mongolia in the Carboniferous and Permian. Systematic collection of Meso-Cenozoic sea urchins, echinoderms from the Ordovician, Leningrad Region. and Estonia, Carbon- iferous echinoderms of the Moscow Syneclise, and Permian echinoderms in the Urals, made it possible to assemble collections of world significance. Arendt (1981) published a number of monographs on fossil sea lilies with unique data on the morphology, symmetry, and ontogeny of individual groups. V.B. Kushlina carefully studied the mysterious Ordovician bolboporites and showed their eocrinoid nature. S.V. Rozhnov described in detail many groups of Early Paleozoic echinoderms, paying special attention to the morphogenesis of individual structures. Many data are summarized in a monograph on the morphogenesis of Pelmatozoic echinoderms (Rozhnov, 2002). The study of the Ordovician deposits of the Leningrad region allowed him to develop a model for the development of the Ordovician evolutionary radiation of the benthic fauna; this model was based on the identification of positive feedbacks between soils and the communities of animals and cyanobacteria living on them. Carboniferous crinoids are actively studied by a young laboratory worker G.V. Mirantsev. Sea urchins were studied by A.N. Soloviev, L.G. Endelman and A.V. Markov. The Cabinet of Echinoderms, and then the Laboratory into which it was included, became the organizational center for the study of echinoderms, thanks to the organization of All-Union/All-Russian conferences on this group. This is a great achievement of A.N. Solovjev.

All laboratory staff actively worked on the problems of historical and individual morphogenesis, actively participating in interdepartmental conferences and 
colloquia on morphogenesis, which were repeatedly organized by the Paleontological Institute. Under the auspices of these scientific conventions, problems of the evolution of symmetry in echinoderms and fourbeam corals, problems of regeneration and its relationship with the emergence of coloniality in corals have been developed (Rozhnov, 2014a, b; Kazantseva and Rozhnov, 2018), and the ontogeny of strophomenid brachiopods has been reconstructed (Madison and Kuzmina, 2020).

The Laboratory of Paleobotany was organized in 1994, with the arrival of V.A. Krassilov at the institute. It is currently headed by N.E. Zavialova. The directions of the laboratory's work were set by the wide range of Krassilov's scientific interests, including the morphology of fossil higher plants, taxonomy, phylogeny, paleoecology, and general issues of evolution (Krassilov, 2003, 2014). During its existence, the laboratory has included enthusiastic researchers (N.V. Bazhenova, A. B. Sokolova, E. V. Karasev, A.V. Bazhenov, N.P. Maslova, N. E. Zavialova, M.V. Tekleva, T.S. Foraponova), including many young people. The range of research includes botanical fossils (large-sized plant remains, spores and pollen) from the Paleozoic to the Cenozoic, and, for comparison, also modern plants (Krassilov, 2010). An extensive arsenal of paleobotanical methods is used, including both traditional light microscopy and scanning and transmission electron microscopy, confocal laser microscopy, and computed tomography. Multidisciplinary research is carried out in collaboration with scientists of various fields (geologists, botanists, palynologists, mycologists) from many laboratories of the institute, other institutes, and universities in Russia and abroad.

Comparison of electron microscopy data and epidermal-cuticular analysis yielded irrefutable evidence that most of the mysterious Devonian plants with thick cuticles are vascular plants, rather than problematic organisms close to algae or lichens, as was previously assumed (Broushkin and Gordenko, 2009).

The study of paleofloristic changes in the Late Permian and Early Triassic time on the territory of the Moscow Syneclise showed that the decrease in taxonomic diversity was gradual, and the sharp change in paleofloristic assemblages in boundary sediments is associated with a decrease in the number of passing taxa and an increase in the number of short-lived taxa. The study of the leaves and generative structures of peltasperm pteridosperms and Voltziales conifers made it possible to suggest phylogenetic transformation pathways of these groups in the Late Paleozoic. It is shown that Voltziales conifers are regularly found in the Lower Permian deposits of the Russian Platform, and that they played a significant role in the Middle and Late Permian. Work continues on understanding ecosystem events occurring in the Permian and Triassic plant communities of the Kuznetsk Basin and Tun- guska Basin; a significant amount of data was assembled on the taxonomic composition of paleofloristic assemblages from all key sections in Western Siberia; curves of changes in taxonomic diversity were constructed for the main groups of higher plants at the border of the Permian and Triassic of the Kuznetsk Basin (Karasev et al., 2019). In the course of a monographic study of the Turonian flora of the Negev Desert, more than 40 species of fossil plants, mostly new to science, have been studied, plant communities have been reconstructed, and traces of phytophagy have been analyzed (Krassilov et al., 2005). On the basis of electron microscopic study of pollen grains of fossil and modern representatives of gnetophytes and platanoids, homeomorphism of palynological characters was revealed. The classification of the Mesozoic gnetophytes was developed; a subdivision of antognetophytes with transitional characters from eugnetophytes to flowering plants is distinguished. The history of the Platanaceae family was reconstructed (Maslova, 2010). The experience of long-term studies of the ultrastructure of the shells of fossil and modern pollen grains and spores of higher plants is analyzed, the features of the interpretation of the data obtained and the prospects for the application of new methods to palynomorphology are considered (Zavialova et al., 2018).

Phytopathological manifestations in fossil plants initiated by various agents are investigated. The paleomycological direction is developing, based on the study of the morphology of micromycetes and paleoecological relationships of plants and fungi (Maslova et al., 2016).

The Laboratory of Paleoichthyology develops the classical directions of paleontology of fish and jawless vertebrates, its research covers the interval from the beginning of the Paleozoic to the present day. The scientific research is based on the works of D.V. Obruchev, a representative of a Russian dynasty of natural scientists, and the founder of the national, and later international, school of paleoichthyology. In the laboratory, using traditional methods, the morphology, phylogeny and taxonomy of primary-aquatic vertebrates, the origin of Agnatha and Gnathostomata, as well as the origin of tetrapods, patterns of the historical dynamics of the paleobiodiversity of lower vertebrates are studied.

Processing the data sets at the species level made it possible to summarize the information in the summary volumes "Jawless and Ancient Fishes" (Novitskaya and Afanassieva, 2004) and "Fossil spiny-finned fishes (Teleostei, Acanthopterygii)" (Bannikov, 2010) of the monographic series "Fossil vertebrates of Russia and adjacent countries".

The extensive research of Novitskaya on the origin of Agnatha and Gnathostomata made it possible to connect the origin of Gnathostomata with the Diplorhina agnathans and to develop a comparative scheme of the ontogeny of modern Cyclostomata and 
Gnathostomata, involving definitive agnathans (Novitskaya, 2015).

The study of the morphology and evolution of the Paleozoic crossopterygians, associated with the emergence of vertebrates on land, carried out by E.I. Vorobweva, showed the mosaic nature and parallelism of the processes of transition to a higher morphophysiological level of development (Vorobyeva, 1992). The discovery of the Early Famennian Jakubsonia confirmed that tetrapods originated earlier than the end of the Late Devonian (Lebedev, 2004). In the study of the basic patterns of the formation of hard covers of vertebrates, the head of the laboratory O.B. Afanassieva (2019), based on modern data on the structure of the exoskeleton in various taxa of ostracoderms, showed that the diversity in its structure is achieved by combining types of tissue anlagen of dentin and bone tissue and methods of their development, and is based on a finite number of developmental options.

The discovery of new freshwater ichthyofaunas of the Paleogene (1964-late 1980s) and Neogene (1959-2000) of the USSR and Mongolia and their subsequent study for the first time created a documentary basis for reconstructing the general history of these communities in the Cenozoic of the Holarctic. Sychevskaya $(1986,1989)$ showed that the Neogene and modern biogeographic structure of these communities was preceded by a fundamentally different spatial distribution inherited from the Late Cretaceous, expressed in the existence of two faunistic regions on the circumboreal land of the Holarctic-Amphipacific and Amphiatlantic. A.F. Bannikov revealed the systematic composition and paleoenvironment of the most important Cenozoic localities of marine fish, Monte Bolca and Monte Solane in Italy (Bannikov, 2014, etc.), and of the Pshekha River in the Northern Caucasus (where several localities of different ages have been discovered).

The main research areas of the Laboratory of Paleoherpetology are Permian-Triassic and Late Mesozoic reptiles and amphibians, their morphology, taxonomy, phylogeny, as well as paleoecology, paleoichnology, biostratigraphy and taphonomy. The latest results of these studies were summarized in a series of monographs (Iskopayemyye pozvonochnyye ..., 2008, 2012).

Academician L.P. Tatarinov obtained important new data on the morphology and evolution of lower tetrapods and considered key issues in the theory of evolution. The research results are summarized in the monograph "Essays on the evolution of reptiles" (Tatarinov, 2009). The process of wide parallel appearance of mammalian traits among ancestral mammal-like reptiles, which he identified, and referred to as mammalization, became a kind of "tracing paper" for identifying similar processes among other groups of animals and plants ("arthropodiza- tion" by A.G. Ponomarenko, "angiospermatization" by V.A. Krassilov, etc.).

M.F. Ivakhnenko substantiated the identification of a new subclass Parareptilia (Ivakhnenko, 1987), a revision of all therapod reptiles of Eastern Europe was carried out and their role in tetrapod communities was analyzed (Ivakhnenko, 2001; Ivakhnenko, 2003).

M.A. Shishkin (together with V.G. Ochev, Saratov State University) established the basis for the modern scheme of biozonal stratification of the continental Triassic deposits of Eastern Europe using vertebrates (Shishkin et al., 2000). He developed and substantiated the epigenetic theory of evolution based on the Schmalhausen-Waddington theory of the evolutionary process as a systemic transformation of the organization of organisms. The ideas of this theory about the maintenance of the final (adult) equilibrium of the developmental system as a real engine of the evolutionary process constituted an alternative to the traditional gene-centered view of evolution (Shishkin, 2010; Shishkin, 2018).

An important direction of the research of the laboratory staff is the study of the stages of development of the fauna of the Permian and Triassic tetrapods of Eastern Europe and two biotic crises of the continental biota, the Middle-Late Permian and PermianTriassic, the largest in the history of life on Earth. A new Sundyr vertebrate fauna was discovered, characterizing the first of these crises, and the Terminal Permian Vyazniki fauna with the world's oldest archosaurs was studied in detail, reflecting the pre-crisis destabilization and change of communities at the Permian-Triassic boundary. The history of the restoration of the tetrapod fauna after the Permian-Triassic crisis with the identification of at least eight evolutionary stages in the Early Triassic is also detailed. The studied sequence of the Permian-Triassic tetrapod faunas of Eastern Europe has no analogues in the world in terms of the detail of the stages of its evolution and can be considered as a reference for intercontinental comparisons (Sennikov and Golubev, 2017).

Regional stratigraphic schemes of the continental Permian and Triassic of Eastern Europe were developed, refined and substantiated using the tetrapod fauna. In the Moscow region, the Middle Jurassic continental fauna of tetrapods, including dinosaurs, has been discovered and described (Alifanov and Sennikov, 2001, etc.). For the first time in Russia, the remains of the earliest Late Permian flying reptiles, weigeltisaurs, have been discovered in the southern Urals, expanding our understanding of their morphology and the appearance of gliding flight in vertebrates (Bulanov and Sennikov, 2010). The earliest known cases of neoplasms of bone tissue in tetrapods were also recorded.

The Cabinet of paleornithology was organized in 2012 to continue the work of E.N. Kurochkin, an eminent researcher of fossil birds. One of the most 
important discoveries in paleornithology was the discovery of the oldest Neornithes bird Ambiortus dementievi, which he described from the Lower Cretaceous of Mongolia, which showed that birds of the modern type existed as early as 120 million years ago (Kurochkin, 1982). Later, for the first time in the history of science, an almost complete skeleton (three-dimensional preservation) of an enantiornithine ("opposite") bird described as Nanantius valifanovi (Kurochkin, 1996) was found in Mongolia. A close relationship between modern (Neornithes) and enantiornithine birds seemed incredible due to the fundamental morphological gap between these groups (Kurochkin, 2006), but the recent discovery of an aberrant Pengornithidae enantiornithine made it possible to develop an original hypothesis of the origin of modern birds from "opposite" birds (Zelenkov, 2017). The key evolutionary innovation that determined the "success" of modern birds is the structure of the main flight joint (Zelenkov, 2017). Significant advances in the study of eggshells: unique data on the diversity of the shell structure in birds have been collected (Mikhailov, 1997a), but also the principles of classification of fossil vertebrate shells, which have already become classical in world science, have been developed (Mikhailov, 1997b). With the help of fossil shells, the evolution of giant flightless birds of the Old World has been reconstructed, unexpectedly showing an Eastern European origin for ostriches (Mikhailov, Zelenkov, 2020). Over the past 40 years, significant advances have also been made in the study of the Cenozoic evolution of birds in Northern Eurasia. Dozens of new taxa (including new orders and families) were described from the territory of the former Soviet Union and Mongolia, which for the first time shed light on the evolution of bird faunas and individual groups of birds in the Paleogene and Neogene. These achievements are summarized in the first monographic compilation on fossil birds of this vast region (Zelenkov and Kurochkin, 2015). The most striking and unexpected discoveries in recent years include the finds of tropical birds (parrots, barbets) in the Miocene of Eastern Siberia (Zelenkov, 2016; Volkova, 2020), as well as one of the largest birds that ever inhabited the Earth, the flightless giant Pachystruthio, in the Pleistocene of Crimea (Zelenkov et al., 2019).

The Mammalian Laboratory is one of the oldest in the institute, and names associated with it include K.K. Flerov, E.I. Belyaeva, I.A. Dubrovo, N.S. Shevyreva, and V.Yu. Reshetov. For a long time, the laboratory was headed by B.A. Trofimov, and after him A.K. Agadjanyan, who was replaced in recent years by A.V. Lopatin. The laboratory staff obtained materials on the Mesozoic mammals of Siberia and Mongolia, fundamentally new in terms of taxonomic and geochronological coverage, analyzed and summarized data on the morphology and phylogeny of mammals from the Late Triassic to the present on a global scale. The modern taxonomy of placental mammals has been analyzed using molecular data, according to which they are grouped into four supraorder level taxa (Xenarthra, Afrotheria, Euarchontoglires, and Laurasiatheria). It has been shown that the fossil record is the only way to test phylogenetic hypotheses obtained from the research material by molecular and morphological methods (Averyanov and Lopatin, 2014). The paleontological data obtained in recent years indicate that, by the middle of the Cretaceous period, Mesozoic mammals had realized all the basic adaptations similar to those of modern small-sized Mammalia, except for active flapping flight (Lopatin and Averianov, 2009). New paleontological and embryological data on the morphogenesis of the auditory ossicles demonstrate the parallel development of the sound transmission mechanism of the middle ear in placentals, marsupials, and monotremes, and also substantiate the independent origin of a number of ancient groups within the Mammaliaformes (Lopatin, 2019b).

The geological time of the formation of placentarity as a complex of characters of long-term gestation of the embryo at the beginning of the Cenozoic has been established. It was shown that it was the trigger mechanism for the accelerated progressive evolution of the central nervous system of Eutheria (Agadjanyan, 2003). A new deep and comprehensive model of the evolution of deer (Cervidae) has been developed, and in the light of modern data-the concept of macroevolution (Vislobokova, 2012, 2017). In recent years, a detailed model of the evolution of the order Lagomorphs has been created, a new model of the origin and adaptive radiation of the order Insectivora has been proposed, and a new evolutionary scheme has been created for voles (Arvicolidae), which are the main Old-World vegetation-eating small mammals (Agadjanyan, 2009). Based on the data obtained, the biostratigraphy of Pliocene and Pleistocene deposits of the European part of Russia was developed. Its main results were included in the modern NeogenePleistocene stratigraphic scheme of the Russian Platform. This outstanding work by A.K. Agadjanyan was nominated for the State Prize.

Based on the data of molecular genetics, an international team of researchers has established that in the second half of the Pleistocene, not only Neanderthal, but also another genetically isolated species of the genus Homo, $\mathrm{H}$. denisensis, lived in Altai. The study of paleontological materials of the Paleolithic sites of the Northwestern Altai made it possible to restore the habitat conditions, biological resources and probable migration routes of Paleolithic humans in this region.

Interinstitutional Laboratory of Bacterial Paleontology of Terrestrial and Extraterrestrial Objects was formed in 1999 after the publication of an article in Geochemistry International on the findings of fossil microorganisms in the Murchison meteorite and a report to the Presidium of the Academy of Sciences on these results in 1999. At that time, the Council for 
Astrobiology was established at the Academy of Sciences, under the Presidium of the Russian Academy of Sciences. Similar results on the Murchison meteorite were obtained at NASA in the Huntsville department by R. Hoover, after which Hoover traveled to Moscow, and joint work between NASA and the Paleontological Institute began. The study commenced of all carbonaceous chondrites, which revealed the presence of numerous fossil remains in this class of meteorites. Since that time, astrobiology began to develop rapidly in different countries, and new journals were organized.

Already in 2004, an international meeting on perspectives in astrobiology (Perspectives in Astrobiology, IOS Press, NATO Science Series, V. 366) was held under the auspices of NATO, the organizers and participants of which were Russian scientists, including from the Paleontological Institute. The development of astrobiological research was expressed in the creation at SPIE of a special section of astrobiology, which held annual meetings in the United States and published, as mentioned above, a series of works of this section. Moreover, already in 2011 the atlas "Fossil Bacteria" was published, in the creation of which, employees of the Paleontological Institute were the main participants. The results of astrobiological work at PIN were also published in a multivolume joint work of the Academy of Sciences and NASA in the series "Space, Biology and Medicine". At the same time, a special astrobiological group was created at the Joint Institute for Nuclear Research, which, together with employees of the Paleontological Institute, Institute of Microbiology and NASA, published a monograph on the study of organic remains of the Orgueil meteorite.

The laboratory researchers did not confine themselves to the narrow research topic of the taxonomic group but joined forces with the staff of other laboratories and other institutes and institutions to solve more general problems. First of all, the laboratories are united by work on general institute topics. Now there are five of them, and all researchers participate in them in different combinations. An equally important role is played by various associations of researchers on various projects, which are organized by initiative groups often in the form of grants from the Russian Foundation for Basic Research, the Russian Science Foundation, programs of the Presidium of the Russian Academy of Sciences, and within the framework of permanent seminars.

In the 1980s, the project "Development and Change of the Organic World in the Mesozoic and Cenozoic" was successfully implemented in the form of a series of seven monographs edited by V.N. Shimansky and A.N. Solovjev. This project was led by Academician V.V. Menner. The results of the research were summarized in the monograph "The boundary between the Mesozoic and Cenozoic in the develop- ment of the organic world" (Shimansky and Solovjev, 1982). Small groups of institute scientists united to receive initiative grants from the Russian Foundation for Basic Research. During the existence of this Foundation, organized in 1992, the staff of the institute received more than 200 grants. In recent years, several important grants from the Russian Science Foundation have been received, which made it possible to organize interesting interdisciplinary research. In particular, wide interdisciplinary research in various combinations and aspects was developed within the framework of the Basic Research Program of the Presidium of the Russian Academy of Sciences. Started under the title "Evolution of the Biosphere" in 2003, it lasted for 17 years under different names, but it was based on the work on the origin and evolution of the biosphere. The Paleontological Institute, being the leading institute, took an active part in the Presidium program. In addition to the Paleontological Institute, many institutes of the Siberian Branch of the Russian Academy of Sciences, Moscow, St. Petersburg, and the Far Eastern and Ural branches of the Russian Academy of Sciences took part in this program. Outstanding scientists, including N.L. Dobretsov, A.E. Kontorovich, V.N. Parmon, N.A. Kolchanov, A.S. Spirin, A.B. Chetverin, G.A. Zavarzin, E.A. BonchOsmolovskaya, Yu.V. Natochin, S.G. Inge-Vechtomov, N.K. Yankovsky, E.M. Galimov, A.I. Grigoriev, S.V. Shestakov, A.P. Derevianko and others actively participated in this project. As a result, more than ten issues of work-reports building a series of monographs were published and several international meetings were held in Novosibirsk, Moscow and abroad. During the existence of this program, remarkable results were achieved in the study of astrocatalysis, the symptomatology of crises in the biosphere, and many problems of evolutionary biology. The leaders of this program at various times were N.L. Dobretsov, G.A. Zavarzin, E.M. Galimov, and A.Yu. Rozanov. Research under this program opened up a number of new directions of research.

Another important program of the RAS Presidium, in which the Institute participated, was devoted to the study of biodiversity. The Institute oversaw the studies of paleobiodiversity.

Based on the structure of these programs, the institute began to actively develop interdisciplinary research within the framework of periodically organized conferences "Morphogenesis in Individual and Historical Development", which in recent years were supplemented by a permanent colloquium of the same name, each meeting of which was devoted to a specific problem of evolutionary developmental biology.

Expansion and intensification of the institute's scientific activities required expanding the possibility of publishing research results. The editor-in-chief of the "Paleontological Journal" A.Yu. Rozanov managed to achieve a gradual but significant increase from four to 


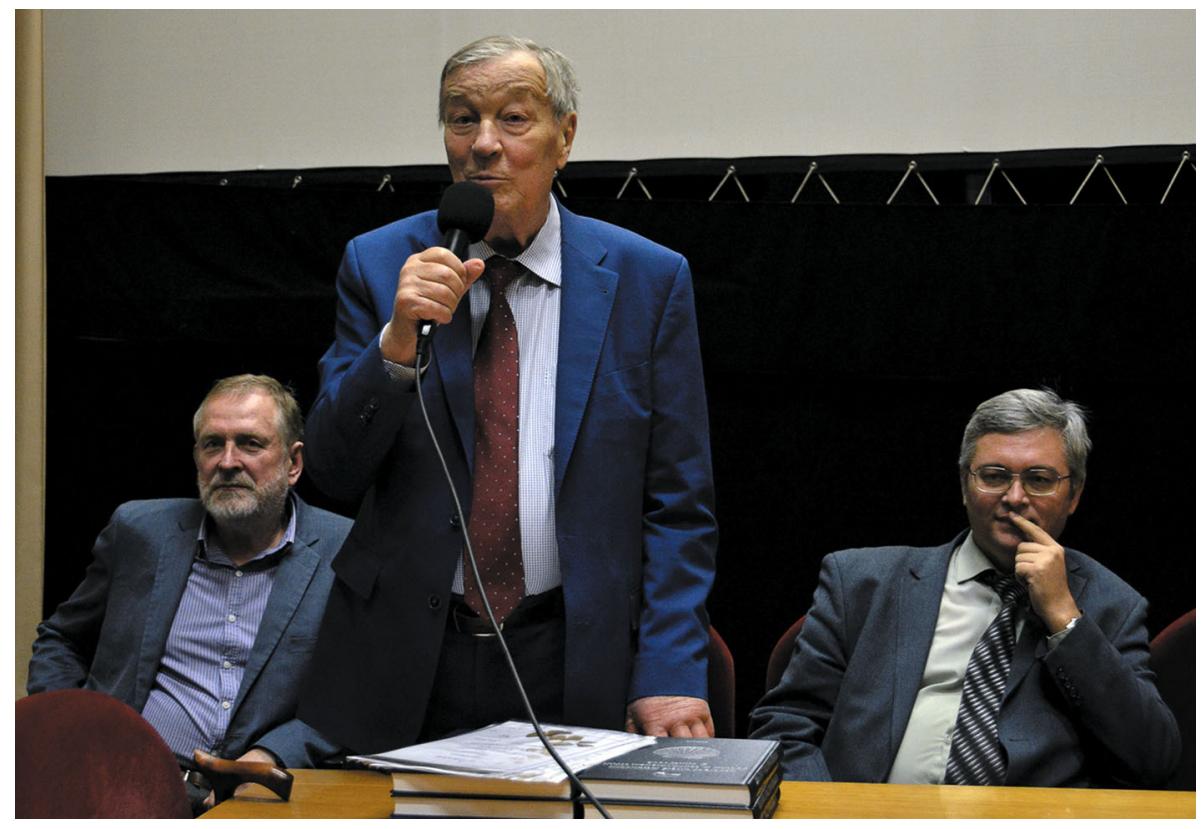

Fig. 8. Directorate of the Institute at the School of Young Paleontologists (S.V. Rozhnov, A.Yu. Rozanov, and A.V. Lopatin). 2014.

12 issues per year. This was a significant event in the development of paleontological work in the Paleontological Institute and in the country in general. At the same time, half of the journal was published in Russian and English, and half in English only. The journal has always been very popular among the paleontological community of the world, and during the time of active journal exchange, the Paleontological Institute sent the Paleontological Journal to foreign countries, in return receiving a fairly wide range of journals published in other countries. Alas, by the early 2000 s, this practice had sharply declined.

The institute now has its own publishing base, capable of creating layouts of books for printing, publishing small brochures and printing posters. M.K. Emelyanova played the main role in its organization and function.

The Scientific Council for Paleobiology and Development of the Organic World of the Department of Biological Sciences of the Russian Academy of Sciences is actively working at the Institute, successfully coordinating paleontological research in Russia. For a long time, this council was headed by A.Yu. Rozanov, and thanks to the activity of the secretary L.N. Bolshakova regularly published reports on its activities. The necessary coordination of research is also carried out through the active participation of the institute scientists in the Paleontological Society at the Academy of Sciences, which celebrated its 100th anniversary in 2018. The presidents of the society were B.S. Sokolov and A.Yu. Rozanov, vice-president S.V. Rozhnov, and many employees are members of the Paleontological Society Council. The Paleontological Society is important for organizing and cementing relationships between paleontologists throughout the country. Annual sessions of the Paleontological Society are held. The work of the Paleontological Society sessions was only interrupted during the blockade of Leningrad, and again in 2020 due to the coronavirus pandemic. The Institute helped revive the publication of the Proceedings of the Paleontological Society after a long hiatus following the collapse of the Soviet Union. The Institute has organized an annual School of Young Paleontologists, where young people present their reports and listen to lectures by leading paleontologists (Fig. 8). This school is complemented by the annual "Paleostrat" conference organized by A.S. Alekseev. The great achievements of the institute are largely associated with its creative scientific environment, and the warm, supportive atmosphere prevailing in the team. This would have been impossible without caring and benevolent colleagues, clearly manifested in I.D. Sukacheva, M.B. Borisoglebskaya, E.V. Shnitnikova, N.V. Egorova, N.K. Goncharova and many other employees of the institute.

The extensive and effective creative work of the research team would not have been possible without the wonderful teams of other departments of the institute: administrators, preparators, workshops. Many people from these departments, in fact, like most academics, have associated most of their adult lives with the institute. They include A.V. Golovanov, A.N. Kolyans, A.G. Tyuvaev, S.V. Bolotin, Yu.F. Orudov, V.G. Barannikov, V.N. Miromanov, A.I. Anikin, S.A. Kharitonov, V.T. Antonova, V.N. Kachanova, and many others. 
Over the 90 years of the Institute's existence, there have been many changes in the methods and directions of work. The studies of some groups faded, while other groups intensified. Many studies of invertebrates were initially driven by the need to develop the morphology and taxonomy of groups important for stratigraphic studies. These were the approaches to the study of brachiopods, bryozoans, corals, fusulinids, and mollusks. To a lesser extent, this applied to vertebrates. From the very beginning A.A. Borissiak determined the biological orientation of the Institute's work, which manifested itself in the results of work in all groups. Apparently, this explains the relatively less developed research on hyperstratigraphic groups associated with micropaleontological methods. Only recently, this has intensified after the creation of the laboratory of protistology. Therefore, there is now a clear tendency towards the study of these taxa, which makes it possible to connect them with modern problems of evolutionary developmental biology, key problems of the evolution of the biosphere and the development of biodiversity. Despite such a significant biological focus of the Institute's research, the basis of paleontology is still the need for a thorough study of the geological conditions of occurrence of fossil remains, their stratigraphic and geographic distribution. A special role is played by the paleontological study of the most ancient Precambrian strata, which is important not only for understanding the first stages of the development of the biosphere, but also for developing topical astrobiological problems.

Thus, the rapid development of paleontology, due to extensive stratigraphic studies and geological surveys of a vast territory, is being stimulated by the demands of modern developmental biology and the need to study the history of the formation of the biosphere in order to overcome crisis situations in the future. The broad possibilities for the Paleontological Institute and the whole of Russian paleontology to confidently fit in with these dominant directions of world research are confirmed by the scientific foundation that has been laid down during the entire existence of the Institute. The characteristic creative enthusiasm of the Institute's team, which is able to overcome the deadening bureaucracy in the organization of science that has so intensified in recent years, helps to realize these opportunities and solve the problems facing the institute.

\section{ACKNOWLEDGMENTS}

The authors are sincerely grateful to the staff of the institute A.K. Agadjanyan, O.B. Afanassieva, E.A. Zhegallo, N.E. Zavialova, N.V. Zelenkov, T.B. Leonova, A.P. Rasnitsyn, and A.G. Sennikov for a fruitful discussion of the materials of the article.

\section{REFERENCES}

Afanasieva, G.A., Alekseeva, R.E., Lazarev, S.S., Manankov, I.N., et al., Paleontologiya Mongolii (Brakhiopody Paleontology of Mongolia. Brachiopods), Moscow: Nauka, 2003.

Afanasieva, M.S. and Amon, E.O., Radiolyarii (Radiolarians), Moscow: Paleontol. Inst. Ross. Akad. Nauk, 2006.

Afanassieva, O.B., The Vertebrate Exoskeleton: Geometric Patterns of the Armor Relief Formation in Early Jawless Vertebrates (Agnatha, Vertebrata), Dokl. Biol. Sci., 2019, vol. 489, no. 1, pp. 161-164.

Agadjanian, A.K., Questions of Early Adaptive Radiation of Mammals, Paleontol. J., 2003, vol. 37, no. 1, pp. 78-91.

Agadjanian, A.K., Small Pliocene-Pleistocene mammals of the Russian Plain, Trudy Paleontol. Inst. Ross Akad Nauk, 2009, vol. 289, pp. 1-676.

Alekseev, A.S. and Goreva, N.V., (Eds). Type and reference Carboniferous sections in the south part of the Moscow Basin. Field trip guidebook, August 11-12, 2009 of the Intern. Field Meeting of the I.U.G.S. Subcommission on Carboniferous Stratigr. "The historical type sections, proposed and potential GSSP of the Carboniferous in Russia". Moscow: Paleontol. Inst. Ross. Akad. Nauk, 2009.

Alekseeva, R.E., Afanasieva, G.A., Barabasheva, E.E., Grunt, T.A., Komarov, V.N., Oleneva, N.V., Pakhnevich, A.V., Roganov, G.V., Shishkina, G.R., and Eichwald, T.P., Brachiopods and Devonian stratigraphy of the Mongol-Okhotsk region. Far East and Eastern Transbaikalia of Russia, Mongolia, Trudy Paleontol. Inst. Ross Akad Nauk, 2006, vol. 285, pp. 1-365.

Alekseeva, R.E., Afanasjeva, G.A., Grechishnikova, I.A., Oleneva N.V., and Pakhnevich A.V. Devonian and Carboniferous brachiopods and biostratigraphy of Transcaucasia, Paleontol. J. 2018, vol. 52, nos. 8, 9, pp. 829-1086.

Alifanov, V.R. and Sennikov, A.G., Discovery of Dinosaur Remains in a Moscow Suburb, Dokl. Earth Sci., 2001, vol. 376, no. 1, pp. 1-3.

Arendt, Yu.A. Three-armed crinoids, Trudy Paleontol. Inst. Akad Nauk SSSR, vol. 189, pp. 1- 194.

Aristov, D.S., Bashkuev, A.S., Golubev, V.K., Gorochov, A.V., Karasev, E.V., Kopylov, D.S., Ponomarenko, A.G., Rasnitsyn, A.P., Rasnitsyn, D.A., Sinitshenkova, N.D., Sukatsheva, I.D., and Vassilenko, D.V., Fossil insects of the Middle and Upper Permian of European Russia, Paleontol. J., 2013, vol. 47, no. 7, pp. 641-832.

Astafieva, M.M., Gerasimenko, L.M., Geptner, A.R., Zhegallo, E.A., Zhmur, S.I., Karpov, G.A., Orleansky, V.K., Ponomarenko, A.G., Rozanov, A Yu., Sumina, E.L., Ushatinskaya, G.T., Hoover, R., and Shkolnik, E.L. Iskopayemyye bakterii i drugiye mikroorganizmy $v$ zemnykh porodakh i astromaterialakh (Fossil Bacteria and other Microorganisms in Terrestrial Rocks and Astromaterials), Moscow: Paleontol. Inst. Ross. Akad. Nauk, 2011.

Astashkin, V.A., Belyaeva, G.V., Esakova, N.V., Osadchaya, D.V., Pakhomov, N.N., Pegel', T.V., Repina, L.N., Rozanov, A.Yu, Zhuravlev, A.Yu. The Cambrian System of the Foldbelts of Russia and Mongolia. Correlation Chart and Explanatory Notes. Trondheim, Norway: Intern. Union of Geol. Sci., Geol. Surv. Norway, 1995.

Astashkin, V.A., Pegel', T.V., Repina, L.N., Rozanov, A.Yu., Shabanov, Yu.Ya., Zhuravlev, A.Yu., Sukhov, S.S., and Sundukov, V.M., The Cambrian System on the Siberian Plat- 
form. Correlation Chart and Explanatory Notes, Herndon: Intern. Union of Geol. Sci., 1991 (Publ. no. 27. 133 pp.).

Atlas of the Peri-Tethys Paleogeographic maps, vol. "Tertiary" Explonatory Notes. Mem. of Peri-Tethys Programme (Popov, S.V., Gontcharova, I.A., Ilyina, L.B., et al.), 2000, Maps 17-23.

Averianov, A.O. and Lopatin, A.V., Origin of placental mammals: current problems, Zool. Zhurn., 2014, T. 93, no. 7, pp. 798-813.

Bannikov, A.F., Iskopayemyye pozvonochnyye Rossii i sopredel'nykh stran. Iskopayemyye kolyucheperyye ryby (Teleostei, Acanthopterygii) (Fossil Vertebrates of Russia and Adjacent Countries. Fossil Spiny-Finned Fishes) (Teleostei, Acanthopterygii), Parin, N.V., Eds., Moscow: GEOS, 2010.

Bannikov, A.F., The systematic composition of the Eocene actinopterygian fish fauna from Monte Bolca, northern Italy, as known to date, Studi Ric. Giacim. Terz. Bolca. Verona, 2014, vol. 15, pp. 23-33.

Baranova, D.V., Kabanov, P.B., and Alekseev, A.S., Fusulinids (Foraminifera), lithofacies and biofacies of the Upper Moscovian (Carboniferous) of the southern Moscow Basin and Oka-Tsna Swell, Paleontol. J., 2014, vol. 48, no. 7, pp. 701-849.

Barskov, I.S., Boiko, M.S., Konovalova, V.A., Leonova, T.B., and Nikolaeva, S.V., Cephalopods in the marine ecosystems of the Paleozoic, Paleontol. J., 2008, vol. 42, no. 11, pp. 1167-1284.

Barskov, I.S., Leonova, T.B., and Shilovsky, O.P., Middle Permian cephalopods of the Volga-Ural region, Paleontol. J., 2014, vol. 48, no. 13, pp. 1331-1414.

Broushkin, A.V. and Gordenko, N.V., Istchenkophyton filiciforme gen. et sp. nov., a new small vascular plant with thick cuticle from the Devonian of Voronezh Region (European Russia), Paleontol. J., 2009 vol. 43, no. 10, pp. 1202-1216.

Bulanov, V.V. and Sennikov, A.G., New Data on the Morphology of Permian Gliding Weigeltisaurid Reptiles, Paleontol. J., 2010, no. 6, pp. 682-694.

Cambrian of the Siberian Platform. Book. 2: Northeast of the Siberian Platform. 13th Int. Field conference of the working group on the stage division of the Cambrian system, Yakutia, Russia, July 20-August 1, 2008, Rozanov A.Yu. and Varlamov, A.I., Eds., Moscow-Novosibirsk, 2008.

Dmitriev, V.Yu., Aristov, D.S., Bashkuev, A.S., Vasilenko, D.V., Vřsanský, P., Gorokhov, A.V., Lukashevich, E.D., Mostovski, M.B., Ponomarenko, A.G., Popov, Yu.A., Rasnitsyn, A.P., Sinitshenkova, N.D., Sukatsheva, I.D., Tarasenkova, M.M., Khramov, A.V., and Shmakov, A.S., and. Insect Diversity from the Carboniferous to Recent, Paleontol. J., 2018, vol. 52, no. 6, pp. 610-619.

Fauna i biostratigrafiya nizhnego kembriya Mongolii (Fauna and biostratigraphy of the Lower Cambrian of Mongolia). Moscow: Nauka, 1996. (Trudy SSMPE, vol. 46, pp. 1-216).

Fedonkin, M.A., Belomorian biota of the Vendian (Precambrian skeletal fauna of the north of the Russian Platform), Trudy Geol. Inst. Akad. Nauk SSSR, 1981, vol. 342, pp. 1-99.

Fedonkin, M.A., The skeletal fauna of the Vendian and its place in the evolution of Metazoa, Trudy Paleontol. Inst. Akad Nauk SSSR, 1987, vol. 226, pp. 1-174.
Gibshman, N.B. and Alekseev, A.S., Marine Algal Flora of the Late Viséan (Early Carboniferous) of the Moscow Basin, Paleontol. J., 2017, vol. 51, no. 3, pp. 86-96.

Gibshman, N.B., Foraminifers from the Serpukhovian Stage Stratotype, the Zabor'e Quarry Site (Moscow region), Strat. Geol. Correl., 2003, vol. 11, no. 1, pp. 36-60.

Gorjunova, R.V., Phylogeny of Paleozoic bryozoans. Trudy Paleontol. Inst. Ross Akad Nauk, 1996, vol. 267, pp. 1-165.

Historical development of the class of insects, Trudy Paleontol. Inst. Akad Nauk SSSR, 1980, vol. 17, pp. 1-269.

History of Insects, Rasnitsyn, A.P., and Quicke, D.L.J., Eds., Dodrecht etc.: Kluwer Acad. Publ., 2002.

Iskopayemyye pozvonochnyye Rossii i sopredel'nykh stran. Beschelyustnyye i drevniye ryby (Fossil vertebrates of Russia and adjacent countries. Jawless and ancient fish), Novitskaya, L.I., Ed., Moscow: GEOS, 2004.

Iskopayemyye pozvonochnyye Rossii i sopredel'nykh stran. Iskopayemyye reptilii i ptitsy. Ch. 1 (Fossil vertebrates of Russia and neighboring countries. Fossil reptiles and birds. Part 1), Ivakhnenko, M.F. and Kurochkin, E.N., Moscow: GEOS, 2008.

Iskopayemyye pozvonochnyye Rossii i sopredel'nykh stran. Iskopayemyye reptilii i ptitsy. Ch. 2 (Fossil vertebrates of Russia and neighboring countries. Fossil reptiles and birds. Part 1), Kurochkin and Lopatin, A.V., Moscow: GEOS, 2012.

Ivakhnenko, M.F., Eotherapsids from the East European Placket (Late Permian), Paleontol. J. 2003, vol. 37, Suppl. 4, pp. 339-465.

Ivakhnenko, M.F., Permian parareptiles of the USSR, Trudy Paleontol. Inst. Akad Nauk SSSR, 1987, vol. 223, pp. 1160.

Ivakhnenko, M.F., Tetrapods of the East European plackate-Late Paleozoic territorial-natural complex. Trudy Paleontol. Inst. Ross Akad Nauk, 2001, vol. 283, pp. 1-200.

Ivantsov, A.Yu., Nagovitsyn, A.L., and Zakrevskaya, M.A., Traces of locomotion of Ediacaran macroorganisms, Geosciences, 2019a.

https://doi.org/10.3390/geosciences9090395

Ivantsov, A.Yu., Trace Fossils of Precambrian Metazoans "Vendobionta" and "Mollusks", Strat. Geol. Correl., 2013, vol. 21, no. 3, pp. 252-264.

Ivantsov, A.Yu., Zakrevskaya, M.A., and Nagovitsyn, A.L., Morphology of integuments of the Precambrian animals, Proarticulata, Invertebrate Zool., 2019b, vol. 16, no. 1, pp. 19-26.

Karasev, E., Forte, G., Coiro, M., and Kustatscher, E. Mutoviaspermum krassilovii gen. et sp. nov.: A peculiar compound ovuliferous conifer cone from the Lopingian (Late Permian) of European Russia (Vologda Region), Intern J. Plant Sci., 2019, vol. 180, no. 8, pp. 779-799.

Kazantseva, E.S. and Rozhnov, S.V., Massovoye poyavleniye regeneratsionnykh pochek $u$ odinochnogo koralla Bothrophyllum conicum Trd (Rugosa) v podmoskovnom karbone, Morfogenez $v$ individual'nom i istoricheskom razvitii i geterokhronii, geterotopii $i$ allometriya (Mass appearance of regenerative buds in a single coral Bothrophyllum conicum Trd (Rugosa) in the Carboniferous near Moscow, Morphogenesis in individual and historical development and heterochrony, heterotopy and allometry). Moscow: Paleontol. Inst. Ross. Akad. Nauk, 2018, pp. 103-121. 
Koromyslova, A.V., Bryozoans of the Latorp and Volkhov horizons (Lower-Middle Ordovician) of the Leningrad Region, Paleontol. J., 2011, vol. 45, no. 8, pp. 887-980.

Krassilov, V., Evolution: System Theory. Sofia: Pensoft, 2014.

Krassilov, V.A., Cercidiphyllum and fossil allies: morphological interpretation and general problems of plant evolution and development. Sofia: Pensoft, 2010.

Krassilov, V.A., Lewy, Z., Nevo, E., and Silantieva, N., Turonian flora of Southern Negev, Israel. Sophia: Pensoft, 2005.

Krassilov, V.A., Terrestrial paleoecology and global changes. Sofia: Pensoft, 2003.

Kurochkin, E.N., A new enantiornithid of the Mongolian Late Cretaceous, and a general appraisal of the infraclass Enantiornithes (Aves), Moscow: Paleontol. Inst. Ross. Akad. Nauk, 1996.

Kurochkin, E.N., A New Order of Birds from the Lower Cretaceous of Mongolia, Dokl. Academy of Sciences of the USSR, 1982, vol. 262, no. 2, pp. 452-455.

Kurochkin, E.N., Parallel evolution of theropod dinosaurs and birds, Ent. Rev., 2006, vol. 85, no. 1, pp. S45-S58.

Lebedev, O.A., A new tetrapod Jakubsonia livnensis from the Early Famennian (Devonian) of Russia and palaeoecological remarks on the Late Devonian tetrapod habitats, Acta Univ. Latviensis, 2004, vol. 679, pp. 79-98.

Leonova, T.B., Permian ammonoids: Classification and phylogeny, Paleontol. J. 2002, vol. 36, Suppl. 1, pp. 1-114.

Leonova, T.B., Permian ammonoids: Biostratigraphic, biogeographical and ecological analysis, Paleontol. J., 2011, vol. 45, no. 10, pp. 1206-1312.

Leonova, T.B., New data on the biogeography of the Permian ammonoid family Perrinitidae, Paleontol. J., 2019, vol. 53, no. 5, pp. 465-470.

Lopatin, A.V., Modern data on the origin and early radiation of mammals, Biol. Bull., 2019a, vol. 47, no. 7, pp. 744750 .

Lopatin, A.V., To the 50th Anniversary of the Joint Russian-Mongolian Paleontological Expedition, Paleontol. J., 2019b, vol. 53, no. 3, pp. 215-227.

Lopatin, A.V. and Averianov, A.O., Mammals that coexisted with dinosaurs finds on Russian territory, Herald of the Russian Academy of Sciences, 2009, vol. 79, no. 3, pp. 268273.

Madison, A.A. and Kuzmina, T.V., The tube-like structures on the juvenile shells of earliest strophomenides and billingsellides as evidence of their life cycle, Lethaia, 2020, vol. 53, no. 1, pp. 91-105.

Makhlina, M.Kh., Alekseev, A.S., Goreva, N.V., Gorjunova, R.V., Isakova, T.N., Kossovaya, O.L., Lazarev, S.S., Lebedev, O.A., and Shkolin, A.A. Sredniy karbon Moskovskoy sineklizy (yuzhnaya chast'), 2. Paleontologicheskaya kharakteristika (Middle Carboniferous of the Moscow Syneclise (Southern Part)), 2. Paleontological characteristics, Moscow: Nauchn. Mir, 2001.

Märss, T., Afanassieva, O., and Blom, H. Biodiversity of the Silurian osteostracans of the East Baltic, Trans. Roy. Soc. Edinb., Earth and Environm. Sci., 2014, vol. 105, pp. 73-148.

Maslova, N.P., Systematics of fossil platanoids and hamamelids, Paleontol. J., 2010, vol. 44, no. 11, pp. 1379-1466.
Maslova, N.P., Vasilenko, D.V., and Kodrul, T.M., Phytopathology in fossil plants: new data, questions of classification, Paleontol. J., 2016, vol. 50, no. 2, pp. 202-208.

Mazaev, A.V., Lower Permian gastropods of Shakhtau (Asselian-Sakmarian Boundary Beds, Southern Cisuralia, $\mathrm{Pa}$ leontol. J., 2019, vol. 53, no. 12, pp. 1237-1345.

Mazaev, A.V., Upper Kazanian (Middle Permian) gastropods of the Volga-Urals Region, Paleontol. J., 2015, vol. 49, no. 8, pp. 869-988.

Mikhailov, K.E., Avian egg-shells: an atlas of scanning electron micrographs, Brit. Ornithol. Club. Occas. Publ., 1997a, no. 3, pp. 1-88.

Mikhailov, K.E., Fossil and recent eggshell in amniotic vertebrates: fine structure, comparative morphology and classification. London: Palaeontol. Assoc., 1997b, pp. 1-80.

Mikhailov, K.E., Zelenkov, N.V., The late Cenozoic history of the ostriches (Aves: Struthionidae), as revealed by fossil eggshell and bone remains, Earth-Sci. Rev., 2020 vol. 208: 103270

Mitta, V.V., Ammonites and stratigraphy of the Upper Bajocian Garantiana garantiana zone in the interfluve between the Kuban and Urup rivers (Northern Caucasus), Palaeontol. J., 2019. vol. 53, no. 11, pp. 1188-1202.

Nevesskaya, L.A., Stages of the evolution of benthos of the Phanerozoic seas. I. Paleozoic, Trudy Paleontol. Inst. Ross Akad Nauk, 1998, vol. 270, pp. 1-503.

Nevesskaya, L.A., Stages of the evolution of benthos of the Phanerozoic seas. II. Mesozoic, Cenozoic. Trudy Paleontol. Inst. Ross Akad Nauk, 1999, vol. 274, pp. 1-203.

Nevesskaya, L.A., Popov, S.V., Gontsharova, I.A., Guzhov, A.V., Yanin, B.T., Polubotko, I.V., Byakov, A.S., and Gavrilova, V.A., Bivalve mollusks of Russia and adjacent countries in the Phanerozoic, Trudy Paleontol. Inst. Ross Akad Nauk, 2013, vol. 294, pp. 1-524.

Nikolaeva, S.V. and Bogoslovsky, B.I., Devonian ammonoids, IV. Cymeniids (Suborders Clymeniina), Trudy Paleontol. Inst. Ross Akad Nauk, 2005, vol. 287, pp. 1-220. Novitskaya, L.I., Predshestvenniki ryb, beschelyustnyye nachalo puti $k$ cheloveku (Precursors of fish, jawless-the Beginning of the Path to Humans), Moscow: GEOS, 2015. Ovechkina, M.N., Calcareous Nannoplankton of the Upper Cretaceous (Campanian and Maastrichtian) from the South and East of the Russian Platform, Trudy Paleontol. Inst. Ross Akad Nauk, 2007, vol. 288, pp. 1-352.

Olferiev, A.G. and Alekseev, A.S., Stratigraficheskaya skhema verkhnemelovykh otlozheniy Vostochno-Yevropeyskoy platformy. Ob"yasnitel'naya zapiska (Stratigraphic diagram of the Upper Cretaceous Deposits of the East European Platform. Explanatory Letter). Moscow: Paleontol. Inst. Ross. Akad. Nauk, 2005.

Paleontologicheskiy institut Akademii nauk SSSR. 19301980 (Paleontological Institute of the USSR Academy of Sciences. 1930-1980), Tatarinov, L.P., Nevesskaya, L.A., Rozanov, A.Yu., and Shimansky, V.N., Trudy Paleontol. Inst. Akad Nauk SSSR, 1980, vol. 184, pp 1-95.

Parkhaev, P.Yu. and Demidenko, Yu.E., Zooproblematica and Mollusca from the Lower Cambrian Meishucun Section (Yunnan, China), and taxonomy and systematics of the Cambrian small shelly fossils of China, Paleontol. J., 2010, vol. 44, no. 8, pp. 883-1161.

Parkhaev, P.Yu., Origin and early evolution of the phylum Mollusca, Paleontol. J., 2017, vol. 51, no. 6, pp. 663-686. 
Popov, S.V., Rostovtseva, Yu.V., Fillippova, N.Yu., Golovina, L.A., Radionova, E.P., Goncharova, I.A., Vernyhorova, Yu.V., Dykan, N.I., Pinchuk, T.N., Iljina, L.B., Koromyslova, A.V., Kozyrenko, T.M., Nikolaeva, I.A., and Viskova, L.A., Paleontology and stratigraphy of the MiddleUpper Miocene of Taman Peninsula. Part 1. Description of key-sections and benthic fossil groups, Paleontol. J., 2016, vol. 50, no. 10 , pp. 1039-1206.

Rannemelovoye ozero Manlai (Early Cretaceous Manlai Lake), Moscow: Nauka, 1980. (Rudy SSMPE, vol. 13, pp. 1-91.

Rasnitsyn, A.P., Bashkuev, A.S., Kopylov, D.S., Lukashevich, E.D., Ponomarenko, A.G., Popov, Yu.A., Rasnitsyn, D.A., Ryzhkova, O.V., Sidorchuk, E.A., Sukatsheva, I.D., and Vorontsov, D.D., Sequence and scale of changes in the terrestrial biota during the Cretaceous (based on materials from fossil resins), Cret. Res., 2016 vol. 61, pp. 234-255.

Rasnitsyn, A.P., Ontology of evolution and methodology of taxonomy, Paleontol. J., 2006, vol. 40, Suppl. 6, pp. 679737.

Rasnitsyn, A.P., Philosophy of evolutionary biology, Zhurn. Obsch. Biol., 2020, vol. 81, no. 1, pp. 54-80.

Rasnitsyn, A.P., The origin and evolution of Hymenoptera, Trudy Paleontol. Inst. Akad. Nauk SSSR, 1980, vol. 174, pp. 1-192.

Rozanov, A.Yu. and Zhegallo, E.A., On the problem of the genesis of ancient phosphorites of Asia, Litol. Polez. Iskop., 1989, no. 3, pp. 67-82.

Rozanov, A.Yu., Debrenn, F., and Zhuravlev, A.Yu., Regular archaeocyates, Trudy Paleontol. Inst. Akad Nauk SSSR, 1989, vol. 233, pp. 1-198.

Rozanov, A.Yu., Lopatin, A.V., Rozhnov, S.V., Schastlivtseva, N.P., Novikov, I.V., Pakhnevich, A.V., Lebedev, O.A., Bulanov, V.V., Alifanov, V.R., Kurochkin, E.N., Agadjanyan, A.K., Gubin, Yu.M., and Zakharenko, G.V., Yu.A. Orlov Paleontological Museum, Lopatin, A.V., Ed., Moscow: Paleontol. Inst. Ross. Akad. Nauk, 2012.

Rozanov, A.Yu., Parkhaev, P.Yu., Demidenko, Yu.E., Karlova, G.A., Korovnikov, I.V., Shabanov, Yu.Ya., Ivantsov, A.Yu., Luchinina, V.A., Malakhovskaya, Ya.E., Melnikova, L.M., Naimark, E.B., Ponomarenko, A.G., Skorlotova, N.A., Sundukov, V.M., Tokarev, D.A., Ushatinskaya, G.T., and Kipriyanova, L.D., Iskopayemyye stratotipov yarusov nizhnego kembriya (Fossils of Stratotypes of the Lower Cambrian Stages), Parkhaev, P.Yu., Ed., Moscow: Paleontol. Inst. Ross. Akad. Nauk, 2010.

Rozanov, A.Yu., Rozhnov, S.V., and Yusupova, T.I., The largest expedition in the practice of world paleontological science: to the 50th anniversary of the Joint Russian-Mongolian paleontological expedition, Vestn. Ross. Akad. Nauk, 2020, vol. 90, no. 8, pp. 65-76.

Rozanov, A.Yu., Zavarzin, G.A., Gerasimenko, L.M., Zhegallo, E.A., Ushatinskaya, G.T., Raaben, M.E., Orleansky, V.K., Shkolnik, E.L., Sergeev, V N., Hoover, R., Abyzov, S.S., Vorobieva, E.A., Soina, V.S., Zvyagintsev, D.G., and Gilichinsky, D.A., Bakterialnaya paleontologiya (Bacterial paleontology). Moscow: Paleontol. Inst. Ross. Akad. Nauk, 2001.

Rozhnov, S.V., Morphogenesis and evolution of crinoids and other pelmatozoan echinoderms in the Early Paleozoic, Paleontol. J., 2002, vol. 36, Suppl. 6, pp. 525-674.
Rozhnov, S.V., Symmetry of echinoderms: From initial bilaterally-asymmetric metamerism to pentaradiality, Natur. Sci., 2014a, vol. 6, no. 4, pp. 171-183.

Rozhnov, S.V., Bilateral symmetry in ontogeny and regeneration of solitary Rugosa (Cnidaria; Paleozoic), Paleontol. J., 2014b, vol. 48 , no. 11 , pp. $1183-1193$.

https://doi.org/10.1134/S0031030114110094

Rozhnov, S.V., 50 let Sovmestnoy rossiysko-mongol'skoy paleontologicheskoy ekspeditsii. Itogi (To 50th Anniversary of the Joint Russian-Mongolian Paleontological Expedition. Summary), Moscow: Ross. Akad. Nauk, 2019.

Rozhnov, S.V., Rozanov, A.Yu., Barsbold, R., and Ariunchimeg, J., Research of fossil invertebrates in Mongolia, Istor. Biol. Issled., 2014, vol. 6, no. 4, pp. 29-42.

Sennikov, A.G. and Golubev, V.K., Sequence of Permian Tetrapod Faunas of Eastern Europe and the Permian-Triassic Ecological Crisis, Paleontol. J., 2017, vol. 51, no. 6, pp. 30-41.

Shimansky, V.N. and Solovjev, A.N., Rubezh mezozoya $i$ kaynozoya $v$ razvitii organicheskogo mira (The boundary between the Mesozoic and Cenozoic in the development of the organic world), Moscow: Nauka, 1982.

Shishkin, M.A., Evolutionary theory and scientific thinking, Paleontol. J., 2010, vol. 44, no. 6, pp. 601-613.

Shishkin, M.A., Evolution as a search for organizational equilibrium, BioSystems, 2018, vol. 173, pp. 174-180.

Shishkin, M.A., Ochev, V.G., Lozovskii, V.R., and Novikov, I.V., Tetrapod biostratigraphy of the Triassic of Eastern Europe, The Age of Dinosaurs in Russia and Mongolia, Benton, M.J., Shishkin, M.A., Unwin, D.M., Kurochkin, E.N. Cambridge: Cambr. Univ. Press, 2000, pp. 120-139.

Shkolnik, E.L., Tang, T., Eganov, E.A., Baturin, G.N., Rozanov, A.Yu., Zhegallo E.A., Xue, Y., Yu, T., Jel, K., Piper, D., and Medrano, M., Priroda fosfatnykh zeren i fosforitov krupneyshikh basseynov mira (The Nature of Phosphate Grains and Phosphorites of the Largest Basins of the World), Vladivostok: Dalnauka, 1999.

Shkolnik, E.L., Zhegallo, E.A., Eganov, E.A., Bogatyrev, B.A., Bugelsky, Yu.Yu., Novikov, V.M., Slukin, A.D., Zhukov, V.V., Myskin, V I., Odokiy, B.N., and Georgievsky, A.F., Biomorfnyye struktury $v$ boksitakh (po rezul'tatam elektronnomikroskopicheskogo izucheniya (Biomorphic structures in bauxite (according to the results of electron microscopic examination)), Moscow: Eslan, 2004.

Shkolnik, E.L., Zhegallo, E.A., Gerasimenko, L.M., and Shuvalova, Yu.V., Uglerodistyye porody $i$ zoloto $v$ nikh basseyna Vitvatersrand, YUAR - issledovaniye s pomoshch'yu elektronnogo mikroskopa, Carbon rocks and gold in them, Witwatersrand Basin, South Africa-electron microscopic examination, Moscow: Eslan, 2005.

Sokolov, B.S., Ocherki stanovleniya venda (Essays on the Formation of the Vendian), Moscow: KMK, 1997.

Stepanova, A.Yu., Late Pleistocene-Holocene and recent Ostracoda of the Laptev Sea and their importance for paleoenvironmental reconstructions, Paleontol. J., 2006, vol. 40, Suppl. 2, pp. 91-204.

Sychevskaya, E.K., Presnovodnaya paleogenovaya ikhtiofauna SSSR i Mongolii (Freshwater Paleogene ichthyofauna of the USSR and Mongolia), Moscow: Nauka, 1986. (Tr. SSMPE, vol. 29, pp. 1-176). 
Sychevskaya, E.K., Presnovodnaya ikhtiofauna neogena Mongolii (Freshwater Neogene ichthyofauna of Mongolia), Moscow: Nauka, 1989. (Trudy SSMPE, vol. 39, pp. 1-157). Tatarinov, L.P., Essays on the evolution of reptiles, Trudy Paleontol. Inst. Ross Akad Nauk, 2009, vol. 291, pp. 1-277. Varlamov, A.I., Grigorieva, N.V., Zhuravlev, A.Yu., Zhuravleva, I.T., Repina, L.N., Rozanov A.Yu., and Shabanov, Yu.Ya. Opisaniye razrezov. Yarusnoye raschleneniye nizhnego kembriya (Stratigrafiya Description of the sections. Stage stratigraphy of the Lower Cambrian). Stratigraphy, Rozanov A.Yu., Sokolov B.S. Eds., Moscow: Nauka, 1984, pp. 20-22.

Varlamov, A.I., Rozanov, A.Yu., Khomentovsky, V.V., Shabanov, Yu.Ya., Abaimova, G.P., Demidenko, Yu.E., Karlova, G.A., Korovnikov, I.V., Luchinina, V.A., Kipriyanova, L.D., Parkhaev, P.Yu., Pegel, T.V., Skorlotova, N.A., Sundukov, V.M., Sukhov, S.S., Fedorov, A.B., and Kipriyanova, L.D., in Kembriy Sibirskoy platformy. Kn. 1: AldanoLenskiy region: 13-ya Mezhdunar. polevaya konf. rab. gr. po yarusnomu raschleneniyu kembriyskoy sistemy, Yakutiya, Rossiya, 20 iyulya - 1 avg. 2008 (Cambrian of the Siberian Platform. Book. 1: Aldan-Lena region: 13th Int. Field conference working group on the stage division of the Cambrian system, Yakutia, Russia, July 20-August 1, 2008), Rozanov, A.Yu. and Varlamov, A.I., Eds. Moscow-Novosibirsk, 2008.

Vendskaya sistema. Istoriko-geologicheskoye i paleontologicheskoye obosnovaniye, 1. Paleontologiya (Vendian system. Historical-Geological and Paleontological Substantiation, 1. Paleontology. Moscow: Nauka, 1985. Vickers-Rich, P. and Rozanov, A., The Great Russian Dinosaurs Exhibition. Australia: Patricia Vickers-Rich, 2018.

Viskova, L.A. and Koromyslova, F.V. The history of study of Post-Paleozoic bryozoans in Russia (results and perspectives), Annals of Bryozoology 3: aspects of the history of research on bryozoans, Wyse Jackson, P.N., \& Spenser Jones, M.E., Eds., Intern. Bryozool. Assoc., 2011, pp. 163199.

Viskova, L.A., New Stenolaematous Bryozoans from the Jurassic of Central European Russia (Moscow City and the Moscow and Kostroma Regions), Paleontol. J., 2008, vol. 42, no. 2, pp. 149-158.

Vislobokova, I.A., Giant deer: origin, evolution, role in the Biosphere, Paleontol. J., 2012, vol. 46, no. 7, pp. 643-775.

Vislobokova, I.A., The concept of macroevolution in view of modern data, Paleontol. J., 2017, vol. 51, no. 8, pp. 799898.

Volkova, N.V., The first fossil barbet (Aves: Ramphastidae) from Siberia, J. Ornithol., 2020, vol. 161, pp. 325-332.

Vorobieva, E.I., Problema proiskhozhdeniya nazemnykh pozvonochnykh (The problem of the Origin of Terrestrial Vertebrates), Moscow: Nauka, 1992.
Voronin, Yu.I., Voronova, L.G., Grigorieva, N.V., Drozdova, N.A., Zhegallo, E.A., Zhuravlev, A.Yu., Ragozina, A.L., Rozanov, A.Yu., Sayutina, T.A., Sysoev, V.A., and Fonin, V.D. Granitsa dokembriya i kembriya $v$ geosinklinal'nykh oblastyakh (opornyy razrez Salany-Gol, MNR) (Precambrian and Cambrian boundary in geosynclinal areas (reference section Salany-Gol, Mongolia)), Moscow: Nauka, 1982 (Trudy SSMPE, no. 18).

Voronova, L.G., Drozdova, N.A., Esakova, N.V., Zhegallo, E.A., Zhuravlev, A.Yu., Rozanov, A.Yu., Sayutina, T.A., and Ushatinskaya, G.T. Fossils of the Lower Cambrian Mackenzie Mountains (Canada), Rozanov, A.Yu., Ed., Trudy Paleontol. Akad Nauk SSSR, 1987, vol. 224, pp. 1108.

Zakrevskaya, M.A., Paleoecological reconstruction of the Ediacaran benthic macroscopic communities of the White Sea (Russia), Palaeogeogr., Palaeoclimatol., Palaeoecol., 2014, vol. 410, pp. 27-38.

Zavialova, N.E., Tekleva, M.V., Polevova, S.V., and Bogdanov, A.G. Electron microscopy for morphology of pollen and spores. Moscow: RIPOL Classic Press, 2018.

Zelenkov, N.V., The first fossil parrot (Aves, Psittaciformes) from Siberia and its implications for the historical biogeography of Psittaciformes, Biol. Letters, 2016, vol. 12, no. 10: 20160717.

Zelenkov, N.V., Early Cretaceous Enantiornithine Birds (Aves, Ornithothoraces) and Establishment of the Ornithuromorpha Morphological Type, Paleontol. J., 2017, vol. 51, no. 6, pp. 628-642.

Zelenkov, N.V. and Kurochkin, E.N., Klass Aves, Iskopayemyye reptilii $i$ ptitsy. Ch. 3 (Class Aves, Fossil reptiles and birds. Part 3), Kurochkin, E.N., Lopatin, A.V. and Zelenkov, N.V., Eds., Moscow: GEOS, 2015, pp. 86-290.

Zelenkov, N.V., Lavrov, A.V., Startsev, D.B., Vislobokova, I.A., and Lopatin, A.V., A giant early Pleistocene bird from Eastern Europe: unexpected component of terrestrial faunas at the time of early Homo arrival, J. Vertebr. Paleontol., 2019, vol. 39: e1605521.

Zhegallo, E.A., Rozanov, A.Yu., Ushatinskaya, G.T., Hoover, R.B., Gerasimenko, L.M., and Ragozina, A.L., Atlas of Microorganisms from Ancient Phosphorites of Khubsugul (Mongolia). Huntsville, Alabama: Paleontol. Inst. RAS; NASA, 2000.

Zherikhin, V.V., Izbrannyye trudy po paleoekologii i filotsenogenetike (Selected Works on Paleoecology and Phylocenogenetics), Moscow: KMK, 2003.

Zherikhin, V.V., Ponomarenko, A.G., and Rasnitsyn, A.P. Vvedeniye $v$ paleoentomologiyu (Introduction to Paleoentomology), Moscow: KMK, 2008.

Translated by $S$. Nikolaeva 